\title{
How Does Law Affect Finance? An Examination of Equity Tunneling in Bulgaria
}

\author{
Vladimir Atanasov*, College of William and Mary \\ Bernard Black, University of Texas at Austin \\ Conrad S. Ciccotello, Georgia State University \\ Stanley B. Gyoshev, Exeter University
}

(forthcoming 2010, Journal of Financial Economics)

European Corporate Governance Institute

Finance Working Paper No. 123/2006

University of Texas, McCombs School of Business

Research Paper No. FIN-04-06

University of Texas Law School

Law and Economics Research Paper No. 80

William Davidson Institute Working Paper No. 742

Available on SSRN at:

$\underline{\text { http://ssrn.com/abstract }=902766}$ 


\title{
How Does Law Affect Finance? An Examination of Equity Tunneling in Bulgaria
}

\author{
Vladimir Atanasov*, College of William and Mary \\ Bernard Black, University of Texas at Austin \\ Conrad Ciccotello, Georgia State University \\ Stanley Gyoshev, Exeter University
}

\begin{abstract}
We model and test the mechanisms through which securities law affects tunneling and tunneling affects firm valuation. In 2002, Bulgaria adopted securities law changes which limit two forms of equity tunneling - dilutive equity offerings and freezeouts. Following the changes, minority shareholders participate equally in secondary equity offers, where before they suffered severe dilution; freezeout offer price/sales ratios quadruple; and Tobin's $q$ rises sharply for firms at high risk of tunneling, relative to lower risk firms. . At the same time, return on assets declines for high-equity-tunneling-risk firms, suggesting that controlling shareholders partly substitute for reduced equity tunneling by engaging in more cash-flow tunneling. We thus present evidence on (i) the importance of legal rules in limiting equity tunneling, (ii) the role of equity tunneling risk as an important factor in determining equity prices; and (iii) substitution by controlling shareholders between different forms of tunneling.
\end{abstract}

Keywords: equity tunneling, preemptive rights, dilution, freezeout, corporate governance, securities law, emerging markets

JEL codes: G32, G34, K22

* Corresponding author: Mason School of Business, College of William and Mary, P.O. Box 8795, Williamsburg, VA 23187, vladimir.atanasov@mason.wm.edu, voice: 757-221-2954, fax: 757-221-2937

We would like to thank an anonymous referee for greatly improving the paper. We are also grateful to Franklin Allen, Marco Becht, Morten Bennedsen, Erik Berglof, Mike Burkart, Petko Dimitrov, Alexander Dyck, John Edmunds, Vladimir Gatchev, Mariassunta Gianetti, Martin Grace, Greg Hebb, Mark Hershey, Clifford Holderness, Laurie Krigman, Wendy Liu, Marina Martynova, David Mauer, Chris Muscarella, Enrico Perotti, Jose Luis PeydroAlcalde, Dimana Rankova, Andrei Shleifer, James Smith, David Stolin, Aris Stouraitis, Per Stromberg, Ajay Subramanian, Josef Zechner, and seminar participants at the American Law and Economics Association Annual Meeting (2006), Fourth Asian Corporate Governance Conference, Canadian Law and Economics Association Annual Meeting (2006), Conference on Empirical Legal Studies (2007), European Corporate Governance Institute Conference on Corporate Governance (2008); European Finance Association Annual Meeting (2007), Financial System Modernization Conference organized by the European Central Bank, and International Research Conference on Corporate Governance in Emerging Markets (Istanbul, 2007), Bulgarian Financial Supervision Commission, College of William and Mary, Georgia State University, New Economic School (Moscow, Russia), Southern Methodist University, Stockholm School of Economics, University of Amsterdam, and University of Kansas for helpful comments. We are indebted to Apostol Apostolov, Roumen Nikolov, Vassil Golemanski, Vladimir Lazarov and Kamen Dikov for kindly providing firm ownership, earnings, leverage and Bulgarian Stock Exchange trade data and to Grzegorz Trojanowski for providing the Matlab code to compute oceanic Shapley Values. This project was funded in part through Grant Number S-LMAQM-00-H-0146 provided by the United State Department of State and administered by the William Davidson Institute. The opinions, findings, conclusions, and recommendations expressed herein are those of the authors and do not necessarily reflect those of the Department of State or the William Davidson Institute. 


\section{Introduction}

Classic finance theory, motivated by the Coase theorem (Coase, 1960), often presumes that financial markets can function well regardless of the legal environment. Yet, a growing literature starting with La Porta, Lopez-de-Silanes, Shleifer and Vishny $(1997,1998)$ provides evidence that the legal environment is a significant factor in explaining capital market growth and development. Most of this research, however, says little about the specific channels by which law affects financial markets. Both legal protections and financial market development are typically estimated in the aggregate and evaluated across countries. This leaves the "law and financial development" literature vulnerable to concerns about endogeneity, measurement error, and omitted-variable biases.

Our paper first provides a simple model which unbundles different forms of "tunneling" (the extraction of firm value by a firm's controlling shareholders or managers, see Johnson, La Porta, Lopez-de-Silanes, and Shleifer, 2000), and derives how each affects firm profitability and valuation. We develop the model partly to extend existing models of tunneling, but primarily to develop predictions which we can test using a natural experiment in Bulgaria, provided by 2002 anti-tunneling reforms.

Prior tunneling models (e.g., Shleifer and Wolfenzon, 2002) are simple two-period models that, explicitly or implicitly, examine only a single form of tunneling (effectively, cashflow tunneling). In our model, in contrast, there is both cash-flow tunneling (diversion of ongoing cash flow) and "equity tunneling" (extraction of value via financial transactions that affect ownership claims, rather than the firm's operations). We model and study empirically two flavors of equity tunneling: dilutive equity offerings (issuance of shares to insiders at below 
market value) and freezeouts (forced sale of minority shares to the controller for below market value).

We then use the model to examine how 2002 changes to Bulgarian securities law affect tunneling. Bulgaria went through mass privatization in 1998, which was followed by extensive equity tunneling. The 2002 legal changes limit both dilution and freezeouts, and allow us to examine how specific rules can affect specific forms of tunneling, firm valuation, and firm profitability (as reported to outside shareholders).

Prior to 2002, Bulgarian firms use equity offerings principally to dilute minority shareholders. When firms issue shares, almost all are purchased by controlling shareholders, often at a large discount to market value. The new law strengthens preemptive rights by requiring public companies to distribute publicly-tradable warrants to all shareholders when they issue shares. After 2002, equity offerings are subscribed to roughly pro rata by minority and majority shareholders and firms begin to issue equity to raise capital.

Prior to the 2002 legal changes, freezeout offers are at large discounts to market value, which has often been already depressed by prior dilutive offerings and investor anticipation of future tunneling. Informal freezeouts ("going dark" transactions) are common, at effective prices approaching zero. During 1999-2001, nearly 500 firms (over half of all the listed firms on the Bulgarian Stock Exchange) either go dark or conduct freezeouts. The new law adds several freezeout protections, including regulatory approval of freezeout terms and a ban on going dark transactions. Post 2002, freezeouts of minority shareholders are at premiums to market value, consistent with those in developed markets (DeAngelo, DeAngelo and Rice, 1984), instead of at severe discounts. The ratio of freezeout offer price to sales roughly quadruples. 
At the same time, there is evidence that insiders respond to reduced opportunity for equity tunneling by engaging in more cash-flow tunneling. Post-2002, ROA declines sharply for firms at high risk of equity tunneling, relative to lower risk firms, in a firm-fixed effects framework with period dummies.

The 2002 legal changes, and controllers' responses to them, also affect equity values. Tobin's $q$ levels rise sharply for high-equity-tunneling-risk firms relative to low-risk firms. The value gains from reduced equity tunneling are presumably partly offset by increased cash-flow tunneling, but there are still large net gains in valuation ratios. These results are economically large and robust to different ways of estimating tunneling risk, and different valuation measures (price/sales, price/earnings and market/book value of equity).

We measure equity tunneling risk in two ways, with consistent results. In our principal specification, we use firm financial and ownership characteristics and pre-law data on equity tunneling events to estimate each firm's delisting and dilution propensities at year-end 2001, just before the law change. Second, we use ownership to directly proxy for equity tunneling risk. We expect firms with a controlling private owner to have high equity tunneling risk because the controlling owner has the power and often the incentive to engage in dilution or freezeout. The control group of lower-equity-tunneling-risk firms is firms without a large private blockholder.

Our results have implications for asset pricing research in emerging markets. In hightunneling risk markets, investors must estimate not only expected cash flows (as in any market) but also tunneling risk. We find evidence that equity tunneling risk varies widely in crosssection, and that Bulgarian investors consider this risk and update their valuation estimates when legal rules change. Equity tunneling risk, as a factor in explaining equity prices and expected returns, can complement some commonly used factors, such as market risk and momentum, and 
interact with others, such as firm size and book/market ratio. Size may correlate with tunneling risk (as we confirm below for Bulgaria), and high book/market ratios could reflect high tunneling risk. Investor pricing of equity tunneling risk factors can also help to explain home country bias (Kang and Stulz, 1997), as local investors may be better equipped to evaluate equity tunneling risk at the firm-level (Black, 2001; Glaeser, Johnson, and Shleifer, 2001).

Prior studies of how specific legal rules - as opposed to overall quality of law - can affect equity tunneling risk, or how this risk affects firm valuations, are limited. On the empirical side, the studies most similar in spirit to ours are Nenova (2005) and Carvalhal-da-Silva and Subramanyam (2007), who examine how changes in Brazilian rules providing takeout rights to common shares during freezeouts affect the premium of common shares over economically similar nonvoting preferred shares. On the theoretical side, Himmelberg, Hubbard and Love (2002) allow tunneling risk to vary across firms, similar to our approach, but study only cashflow tunneling. ${ }^{1}$ Our paper is also related to work which examines the connection between the overall quality of a country's legal system and firm behavior or financial contracting practices. ${ }^{2}$

The remainder of the paper is structured as follows. Section 2 develops a model of how equity tunneling through dilutive offerings and below-market freezeouts affects minority

${ }^{1}$ Other related studies, in addition to those cited above, include Black (2001a) and La Porta, Lopez-de-Silanes, and Shleifer (2006), who assess which aspects of securities law predict stronger securities markets, Beck, DemirgucKunt, and Levine (2005), who examine the effects of different aspects of legal systems on firm's access to external finance, Bhattacharya and Daouk (2002), who find a relationship between enforced insider trading laws and the cost of equity capital; and Jiang, Lee and Yue (2008), who report on, but do not directly study, efforts by Chinese regulators to limit cash flow tunneling by parent companies from public subsidiaries. Studies that report evidence of equity dilution in emerging markets include Black, Kraakman and Tarassova (2000) and Baek, Kang and Lee (2006). Studies of value extraction through formal freeezeouts include Gilson and Gordon (2003), and Bates, Lemmon and Linck (2006). Studies of going dark transactions include Marosi and Masoud (2007) and Leuz, Triantis and Wang (2008).

${ }^{2}$ Examples include Qian and Strahan (2007) (effect of creditor protection on structure of bank loans), Lerner and Schoar (2005) (effect of legal environment on form of venture capital investment), Laeven and Woodruff (2007) (effect of judicial quality on firm size), Doidge, Karolyi and Stulz (2007) and Durnev and Fauver (2007) (connection between quality of legal institutions and firms' governance choices). 
shareholder valuations. Section 3 applies the model to the Bulgarian context and derives testable predictions. Section 4 describes the data we rely on. Section 5 provides empirical results on the effect of the 2002 legal changes on equity tunneling mechanisms (equity dilution and freezeout). Section 6 reports results on the relations among tunneling risk, firm profitability, and equity valuations. Section 7 concludes.

\section{A model of cash-flow and equity tunneling}

We begin by developing a model of cash-flow and equity tunneling. Prior tunneling models are highly stylized, and use a two-period framework, which does not permit one to distinguish between forms of tunneling (Burkart, Gromb, and Panunzi, 1998; Shleifer and Wolfenzon, 2002; La Porta, Lopez-de-Silanes, Shleifer and Vishny, 2002; Bertrand, Mehta, and Mullainathan, 2002; Djankov, La Porta, Lopez-de-Silanes and Shleifer, 2008). A single parameter typically captures the cost of tunneling (e.g., Shleifer and Wolfenzon, 2002). This cost increases with the degree of tunneling, as it must for the model to have an interior solution, but the cost is not directly connected to legal constraints. In contrast, we develop a multiperiod model with both cash-flow and equity tunneling and derive: (1) how legal rules can affect particular types of tunneling, and (2) how different types of tunneling should affect firm profitability and valuation. The model is partial equilibrium in nature - prices for minority shares are in equilibrium, but we treat ownership as exogenous and do not model the controller's decision on how much to tunnel. Treating ownership as exogenous is appropriate for our empirical setting, in which ownership stakes largely flow from the 1998 mass privatization.

In our model, minority shareholders infer, based on the legal environment and limited information about each company, the extent of cash-flow tunneling and the probability and magnitude of two forms of equity tunneling - dilutive equity offerings and freezeouts. Changes 
in law cause minority shareholders to update their estimates and thus the price they are willing to pay for shares.

\subsection{Model setup}

There are $N$ firms in the economy, indexed by $n$, and three relevant time periods, indexed by $t(t=0,1$, or 2$)$. We generally focus on a typical firm, suppress the $n$-subscript, and assume that this firm initially has one share outstanding. We assume an all-equity firm. The firm has a controlling shareholder $C$, who initially owns $\alpha_{0}$ shares, and minority shareholders who own the remaining $\left(1-\alpha_{0}\right)$ shares.

Define the firm's "intrinsic value" per share with no tunneling as $V_{\text {no-tun }}$, and its intrinsic income per share as $E_{n o-t u n}$. The firm has assets $A_{0}$. We assume that cash-flow tunneling affects earnings but not assets. The firm's no-tunneling return on assets is $R O A_{n o-t u n}=E_{n o-t u n} / A_{0}$. The controlling shareholder engages in cash-flow tunneling, diverting a fraction $d_{c f}$ of $E_{n o-t u n}$. Minority shareholders observe only the firm's income at $t=0$ after cash-flow tunneling:

$$
E_{\text {obs }}=E_{n o-t u n}\left(1-d_{c f}\right)^{3}
$$

Let shareholders value shares using a simple no-growth discounted cash flow model, in which all observed cash flow is paid out as dividends, cash-flow tunneling is expected to be permanent, and the discount rate $r$ does not depend on the type or level of tunneling. ${ }^{4}$ The firm's per-share value to minority shareholders, with cash-flow tunneling but no equity tunneling, $V_{\text {no-eq }}$, equals:

\footnotetext{
${ }^{3}$ We do not model the determinants of $d_{c f}$. See Durnev and Kim (2005) for a model of cash-flow tunneling.

${ }^{4}$ In follow-up work, we extend the model presented here to a continuous time/infinite horizon framework, and allow for positive growth. See Atanasov, Black \& Ciccotello (2009). These extensions do not affect the model predictions we test below.
} 


$$
V_{n o-e q}=E_{o b s} * \frac{1}{r}=V_{n o-e q}\left(1-d_{c f}\right)
$$

The controller can also engage in equity tunneling through share dilution or freezeout. Minority shareholders value the firm taking into account the risk of future equity tunneling. Thus, the firm's shares will trade at a price $P_{0}<V_{\text {no-eq. }}$. We assume that minority investors can estimate firm-level equity tunneling risk based on legal rules, the characteristics of the firm and the controller, and experience at other firms. Their estimates are correct on average, but they do not know which firms will engage in equity tunneling.

For simplicity, we assume that dilution happens only once (at $t=1$ ) and that freezeout occurs only at $t=2$, and only following a dilutive offering. The model algebra would become more complex, but neither the intuition nor the central empirical predictions would change if we included a "direct to delisting" channel. At $t=1$, the controlling shareholder will cause the firm, with probability $\pi_{d}$, to issue $i$ new shares to its existing shareholders at a discount $d_{\text {dilut }}$ to the firm's value before equity tunneling $V_{\text {no-eq }}$. If a dilutive offering occurs, there is a further probability $\pi_{f}$ that at $t=2$, the controlling shareholder will acquire all minority shares through a tender offer at a discount $d_{\text {freeze }}$ to the value of minority shares after dilution but with no freezeout $V_{\text {no-freeze }}$.

\subsection{Specific equity tunneling mechanisms}

In this sub-section we model how tunneling through dilution and freezeout affects firm profitability and valuation.

\subsubsection{Period 1: Dilution}

At time $t=1$, the firm issues $i$ shares at a discounted price $P_{\text {dilut }}=V_{\text {no-eq }} *\left(1-d_{\text {dilut }}\right)$. Because $P_{0}$ is less than $V_{n o-e q}$, the discount to no-equity-tunneling value $d_{\text {dilut }}$ is not directly observed, and exceeds the observed discount to market price. The minority shareholders acquire 
a fraction $k^{*}\left(1-\alpha_{0}\right)$ of the newly issued shares, where $k$ is the fractional take-up of shares by minority shareholders, relative to the number needed to maintain their percentage ownership. If minority shareholders buy no shares, then $k=0$; if they buy shares pro rata, then $k=1$; if the firm issues new shares principally to outside investors, then $k>1$. Since the shares are offered at a discount to intrinsic value, the controlling shareholder often has an incentive to minimize $k$, to the extent permitted by law.

After the offering, the firm will have $(1+i)$ outstanding shares, of which minority shareholders will own a fraction:

$$
\left(1-\alpha_{1}\right)=\frac{\left(1-\alpha_{0}\right)+k\left(1-\alpha_{0}\right) i}{(1+i)}=\frac{\left(1-\alpha_{0}\right)\left[1+k^{*} i\right]}{(1+i)}
$$

After the issuance, the firm's no-freezeout value will be $\left[1+i *\left(1-d_{\text {dilut }}\right)\right]^{*} V_{n o-e q}$, and the per-share value of minority shares will drop to:

$$
V_{\text {no-freeze }}=\frac{\left(1+i^{*}\left(1-d_{\text {dilut }}\right)\right)}{1+i} * V_{n o-e q}=\left(1-d_{\text {dilut }} \frac{i}{(1+i)}\right) V_{n o-e q}
$$

Minority shareholder wealth, assuming no future freezeout, will decline by a fraction equal to (all proofs are in the Appendix):

$$
D_{\text {dilut }}=d_{\text {dilut }} \frac{i}{1+i}(1-k)
$$

If there are no legal protections against dilutive share offerings, then $d_{\text {dilut }}$ can approach 1 , $k$ can approach $0, i$ can approach $\infty$, and the controller can acquire an arbitrarily large number of shares at an arbitrarily low price, thus expropriating the minority shareholders' initial wealth $D_{\text {dilut }} \approx 1$. Most legal systems, however, limit dilutive offerings in some way (Atanasov, Durnev, Fauver, and Litvak, 2008). Based on Equation (4), these rules can be classified into three main groups: (i) preemptive rights which attempt to bring $k$ closer to one; (ii) minimum pricing rules 
that limit $d_{\text {dilut }}$; and (iii) minority shareholder approval rules, which let the minority limit any of these parameters, but usually apply above a minimum offering size (e.g. $i>0.2$ ).

\subsubsection{Period 2: Freezeout}

We next analyze the post-dilution scenario in which, at $t=2$, the controlling shareholder freezes out the minority shareholders at a price $P_{\text {freeze }}$ which is at a discount $d_{\text {freeze }}$ to the nofreezeout per-share value:

$$
P_{\text {freeze }}=V_{\text {no-freeze }}\left(1-d_{\text {freeze }}\right)=V_{\text {no-eq }}\left[1-d_{\text {dilut }} \frac{i}{1+i}\right]\left(1-d_{\text {freeze }}\right)
$$

The combination of dilution and subsequent freezeout reduces minority shareholder wealth by a fraction (proof in the Appendix):

$$
D_{\text {freeze }}=\frac{\left(1-\alpha_{1}\right) * V_{n o-\text { freeze }} * d_{\text {freeze }}}{\left(1-\alpha_{0}\right) * V_{n o-\ell q}}=\frac{\left[1+k^{*} i\right]}{(1+i)}\left[1-d_{\text {dilut }} \frac{i}{1+i}\right] d_{\text {freeze }}
$$

With no legal protections, the controlling shareholder can offer an arbitrarily low freezeout price, so $d_{\text {freeze }}$ can approach 1 , and the minority shareholders' remaining wealth is expropriated. However, law can limit discounted freezeout offers through some or all of appraisal rights, minimum price rules, fiduciary duty rules, minority shareholder approval, or regulatory approval.

\subsection{Equity tunneling and equilibrium share prices}

We next model how equity tunneling affects equilibrium share prices. To simplify the algebra while maintaining the intuition, we assume that a dilutive offering will be large $(i>>1)$. The post-dilution, no-freezeout fractional wealth loss to minority shareholders from the offering will be $D_{\text {dilut }}=d_{\text {dilut }}(1-k)$. Investors will realize the following payoffs:

No dilution or freezeout: $V_{\text {no-eq }}$ with probability $\left(1-\pi_{d}\right)$ 
Dilution but no freezeout: $\left[1-d_{d i l u t}(1-k)\right] V_{n o-e q}$ with probability $\pi_{d}\left(1-\pi_{f}\right)$

Dilution and freezeout: $\left[1-d_{d i l u t}(1-k)\right]\left(1-d_{\text {freeze }}\right) V_{\text {no-eq }}$ with probability $\pi_{d}^{*} \pi_{f}$

We can combine these payoffs to determine the equilibrium price of minority shares at $t=0$.

Proposition 1: If dilutive offerings are large $(i>>1)$, the market price of minority shares at $t=$ 0 will equal:

$$
P_{0}=V_{n o-e q} \times\left(1-d_{e q}\right)=V_{n o-t u n} \times\left(1-d_{c f}\right) \times\left(1-d_{e q}\right)
$$

Where $d_{e q}$ is the discount due to expected future equity tunneling:

$$
d_{e q}=\pi_{d} *\left\{1-\left[1-d_{\text {dilut }}(1-k)\right]\left(1-\pi_{f} d_{\text {freeze }}\right)\right\}
$$

We next derive expressions for Tobin's $q$ and ROA as a function of the model parameters.

Proposition 2: The expressions for ROA and Tobin's $q$ are:

$$
\begin{gathered}
R O A_{o b s}=\frac{E_{o b s}}{A_{0}}=\frac{E_{n o-t u n}\left(1-d_{c f}\right)}{A_{0}}=R O A_{n o-t u n}\left(1-d_{c f}\right) \\
q_{o b s}=\frac{P_{0}}{A_{0}}=\frac{R O A_{n o-t u n}\left(1-d_{c f}\right)}{r}\left(1-d_{e q}\right)=\frac{R O A_{o b s}}{r}\left(1-d_{e q}\right)
\end{gathered}
$$

We can distinguish empirically between different types of tunneling by using a combination of these financial metrics. Cash-flow tunneling will affect both ROA and Tobin's q. Equity tunneling will affect Tobin's $q$, but not ROA. Thus, it may still be feasible empirically to estimate the effects of equity tunneling on Tobin's $q$ (or similar metrics such as market/book or price/sales) by controlling for ROA as a proxy for cash-flow tunneling.

\subsection{Comparative statics}

From Propositions 1 and 2, we can readily derive comparative statics expressions for how changes in $d_{\mathrm{cf}}$ and the five parameters that enter the expression for $d_{e q}-k, d_{\text {dilut }}, d_{\text {freeze }}, \pi_{f}$, and $\pi_{d}$ 
- affect ROA and Tobin's $q$. We summarize these comparative statics in Table 1, Panel A.

Decreasing the risk of dilution (captured by $k, \pi_{d}$, and $d_{d i l u t}$ ) or freezeout (captured by $\pi_{f}$ and $d_{\text {freeze }}$ ) reduces $d_{e q}$ and increases Tobin's q.

There are also important interaction effects. First, the effect on share value from decreasing dilution (freezeout) risk is lower when freezeout (dilution) risk is higher. Indeed, if freezeout risk at $t=2$ is large enough, even strong preemptive rights and a large discount will not induce minority shareholders to buy shares at $t=1$ (see Appendix for formal discussion). The intuition is that to buy shares at a discount, but then get frozen out at an even lower price, is to “throw good money after bad." Thus, legal protections against dilution and freezeout work in tandem to reduce the overall equity tunneling discount. Second, a change in legal rules that reduces the tunneling discounts $d_{\text {dilut }}$ and $d_{\text {freeze }}$ makes tunneling less profitable and may therefore may make it less likely (lower $\pi_{d}$ and $\pi_{f}$ ). Third, cash-flow tunneling and equity tunneling may be either complements or substitutes - if legal rules restrict one form of tunneling, controllers may react by doing more or less of other forms.

\subsection{A numerical example}

A numerical example, using inputs which we consider to be realistic for Bulgaria, can provide perspective on the model implications, and the potential for substitution between equity and cash-flow tunneling. Consider two companies - A and B - with identical no-tunneling performance and cost of capital $-R O A_{n o-t u n}=r=10 \%$. The two companies are in a country with poor legal protections (Bulgaria before 2002), so that $d_{\text {dilut }}=d_{\text {freeze }}=0.6, k=0$. Investors see Company A as having high equity tunneling risk, with $\pi_{d, A}=\pi_{f, A}=0.75$, but view Company $\mathrm{B}$ as unlikely to engage in equity tunneling, with $\pi_{d, B}=\pi_{f, B}=0$. For cash-flow tunneling the situation 
is reversed - Company A does not engage in cash-flow tunneling $\left(d_{c f, A}=0\right)$, while Company B's managers divert $25 \%$ of its cash flow $\left(d_{c f, B}=0.25\right)$.

Assume next that new laws regulating dilution and freezeout cause $k$ to increase to 1 , and $d_{\text {freeze }}$ to drop to 0 . In response to lost equity tunneling opportunities, Company A's controller starts diverting cash flow, so $d_{c f, A}$ rises to 0.25 . Increased cash-flow tunneling by firms like A provides "cover" for Company B's managers, who increase their cash-flow tunneling $d_{c f, B}$ to 0.35 .

Table 1, Panel B shows the changes in ROA and Tobin's $q$ for the two companies. Company A's ROA drops, but Tobin's $q$ increases sharply due to the drop in equity tunneling risk. In contrast, Company B's shows a drop in both ROA and Tobin's $q$ due to higher cash-flow tunneling and no change in equity tunneling risk.

\subsection{Leverage and taxes}

Our model assumes all-equity financing and no taxes. We summarize here how adding leverage and taxes will change the model predictions. Leverage will affect the extent of cashflow tunneling, because leveraged firms have committed some of their cash flow to debt repayment (Friedman, Johnson, and Mitton, 2003). Tax policies can affect the firm's overall cost of capital $r$, and can affect cash-flow tunneling by giving the government a stake in the firm's earnings and thus an incentive to limit cash-flow tunneling (Dyck and Zingales, 2004).

Equity tunneling can affect the value of debt. For example, even a dilutive offering may inject some new equity capital into the firm, which other things equal should reduce default risk and increase debt value. In contrast, a freezeout in which minority shares are purchased with corporate cash (either directly, or through the controller withdrawing cash after taking the firm private) will remove equity capital and should decrease debt value, other things equal. These 
second order effects aside, adding leverage and taxes will not alter significantly the equations above (one would replace earnings in the model with EBIT).

\section{Applying the theoretical framework to Bulgaria - empirical predictions}

In this section we apply our theoretical framework to Bulgaria both before and after legal changes enacted in 2002, and develop testable predictions about the impact of these changes.

\subsection{Preemptive and appraisal rights in Bulgarian law}

Pre-2002 dilution. Prior to 2002, there were no minimum price rules for secondary equity issues, and thus no limits on $d_{d i l u t}$, other than a rule requiring shares to be issued for no less than par value. Shareholders had preemptive rights but notice periods were short, notice requirements were often not enforced, and the rights were not tradable. Moreover, freezeout risk was high, so minority shareholders would rationally not participate in equity offerings even at a large discount to intrinsic share value. Before the 2002 reforms, dilutive offerings were common (see Table 4).

Pre-2002 freezeouts. Prior to 2002, freezeout prices had to at least equal the firm's threemonth volume-weighted average stock price. However, the market was also very illiquid. Controlling shareholders could freeze out minority shareholders at very low prices using one or more of several methods. First, they could reduce the market price through a dilutive offering. Second, they could manipulate the weighted average stock price by engaging in large trades with related parties at low prices. Third, many firms' shares did not trade at all in a three-month period. Controllers could then simply delist the company without making any offer to minority shareholders. The delisted company would no longer be subject to the securities law, and would be governed only by the Bulgarian Commercial Code, which offers no protections against dilutive offers or freezeouts, and does not require companies to provide financial statements to 
shareholders. A going dark transaction was likely to be equivalent to a freezeout at a close to zero price. Many going dark transactions were followed by dilutive offerings.

Legal reform. In the summer of 2001, Bulgaria elected a new government headed by the former Bulgarian king. One government priority was to improve capital markets. In December 2001 the government proposed, and the Bulgarian Parliament soon thereafter adopted, several changes to the securities laws. Table 2 summarizes these changes. The changes became effective in June 2002, but in practice were enforced by the Bulgarian securities agency from the beginning of 2002 .

The new rules strengthen preemptive rights by allowing a public company to issue shares only by distributing preemptive rights to all shareholders, which are traded on the Bulgarian Stock Exchange. With regard to freezeouts, the new law requires a tender offer for all minority shares when a shareholder reaches $50 \%, 67 \%$, or $90 \%$ ownership. Delisting is allowed only after reaching $90 \%$ ownership. The tender offer price must be approved by a majority of the minority shareholders, and approved as fair to minority shareholders by the securities regulator. The regulator computes a minimum fair price using a combination of $D C F$ valuation and comparison to peer firms. The freezeout price must equal or exceed the greater of this fair price or the threemonth weighted average share price.

The new government also reorganized and increased the powers of the securities regulator. The newly established Financial Supervision Commission (FSC) succeeded the Bulgarian Securities and Stock Exchange Commission. The FSC has subsequently issued several important regulations that strengthen enforcement and clarify minority shareholder protections, and has often required majority shareholders to increase freezeout prices. 


\subsection{Empirical predictions}

First, we test whether $k$ (minority participation in equity issues) increases following the legal changes. We cannot observe $k$ directly. However, we observe the controller's pre-offering ownership ( $\left.\alpha_{0}\right)$, post-offering ownership $\left(\alpha_{1}\right)$, and the number of new shares issued $(i)$, so we can estimate $k$ as:

$$
1-\frac{\left(1-\alpha_{1}\right)}{\left(1-\alpha_{0}\right)}=\frac{i}{(1+i)}(1-k)
$$

The right-hand-side of Equation (11) provides a measure of dilution. It equals 1 if minority shareholders are completely diluted $(k=0) ; 0$ if they participate pro rata $(\mathrm{k}=1)$; and is negative if the firm raises capital principally from outside investors $(k>1)$. The term $i /(1+i)$ is a measure of offering size. We estimate $(1-k)$ empirically by regressing the left hand side of Equation (11) on $i /(1+i)$. We predict that $(1-k)$ declines (outside shareholder participation increases) after the legal changes.

Second, we test whether the legal changes affect freezeout discounts. For going dark transactions, we can only observe that these transactions are common pre-law and are no longer possible post-law. We can, however, compare pre- versus post-law pricing in explicit freezeouts. We predict that freezeout prices should increase post-law.

Third, we test whether restrictions on equity tunneling lead controllers to substitute from equity tunneling into greater cash-flow tunneling. If so, then the profitability of high-equitytunneling-risk firms should decline post-law, relative to lower-risk firms.

Fourth, we predict that Tobin's $q$ levels will increase post-law for firms at high risk of equity tunneling, relative to lower-risk firms. We do so both with and without controlling for changes in observed profitability, measured by ROA. A post-law increase in Tobin's $q$ for high- 
equity-tunneling-risk firms, controlling for changes in ROA, offers evidence consistent with the limits on equity tunneling causing higher valuations of high-tunneling-risk firms, controlling for any change in cash-flow tunneling that may result from loss of equity tunneling opportunities. A post-law increase in Tobin's $q$ for high-equity-tunneling-risk firms, without controlling for ROA, offers evidence consistent with the limits on equity tunneling causing higher overall valuations of high-equity-tunneling-risk firms, even if controllers of these firms substitute from equity tunneling into greater cash-flow tunneling.

\subsection{Empirical strategy: Identifying a control group}

A central empirical challenge for our pre- vs. post-law comparisons, is to identify an appropriate control group of firms, which will let us separate the effects of a change in equity tunneling rules from other concurrent changes in the economic or legal environment affecting Bulgarian firms (for example, the new government reduced the capital gains tax, see Table 2). To study the change in the dilution parameter $k$, we have a partial control group - firms which delist prior to 2002. Because these firms are private, they are not affected by the 2002 law, so we expect no postlaw change in $k$ for equity offerings. The dramatic change we observe in $k$ values, from a pre-law mean of about 0 prelaw to a post-law mean of about 1 , also makes it likely that the law change was a contributing factor.

For change in freezeout prices, our control group is firms that do not undergo freezeouts. For ROA and Tobin's $q$, our principal strategy is to study changes in these metrics for firms at high risk of equity tunneling, using low-equity-tunneling risk firms as a control group to capture general changes in the business environment. We need to find suitable proxies for equity tunneling risk. Our principal approach is to use the pre-law tunneling events to estimate firmlevel propensities to dilute and delist. We estimate logit models of dilution and freezeout using 
all privatized firms. We use the logit coefficients to estimate dilution and freezeout propensities tunprop $_{d, i}$ and tunprop $_{f, i}$ for firms which remain public at the end of 2001.

We then ask whether these propensities predict post-law changes in ROA and Tobin's $q$. We run the following firm fixed effects regression models:

$$
\begin{aligned}
& \mathrm{R} 1: R O A_{i t}=\alpha+A_{i}+B_{t}+\Delta * \text { postlaw }+\sum_{j=d, f}\left(\beta_{j} * \text { tunprop }_{j, i} * \text { postlaw }\right)+\varepsilon_{i t} \\
& \mathrm{R} 2: q_{i t}=\alpha+A_{i}+B_{t}+\Delta * \text { postlaw }+\sum_{j=d, f}\left(\beta_{j}^{*} \text { tunprop } j, i^{*} \text { postlaw }\right)+R O A_{i t}+\varepsilon_{i t}
\end{aligned}
$$

where $i$ indexes companies and $t$ indexes time; $A_{i}$ are firm fixed effects which control for unobserved, time-invariant differences between firms; $B_{t}$ are time fixed-effects, which control for country-wide changes (like the capital gains tax reduction); postlaw is a post-law-change dummy variable (=1 after the law change, 0 before). The coefficient on postlaw gives the predicted change in ROA or $q$ for a hypothetical firm with zero tunneling propensities. The $\beta_{d}$ and $\beta_{f}$ predict the change in ROA or $q$ for a hypothetical 0 -to- 1 change in the respective tunneling propensity. We include ROA in the Tobin's $q$ regression if we want to control for changes in (observed) profitability, and thus control for changes in cash-flow tunneling.

Our second approach is to form an explicit low-equity-tunneling-risk control group and use differences-in-differences (DiD) estimation (see Bertrand, Duflo and Mullainathan, 2004). We form a control group in two ways. First, we treat firms with below median propensity for both dilution and freezeout as the control group, and other firms as the treatment group. Second, we predict that firms with a controlling private owner will be more likely to engage in equity tunneling, since this person can control the firm's decisions. We treat firms with no $20 \%$ private owner as the control group.

We estimate the following DiD equation:

$$
q_{i t}=\alpha+A_{i}+B_{t}+\left(\Delta^{*} \text { postlaw }\right)+\left(\beta^{*} \text { postlaw } * \text { treatdummy }\right)+\varepsilon_{i t}
$$


where treatdummy $=1$ for treatment group firms, 0 otherwise, and the notation is otherwise the same as in Equation12. The coefficient $\beta$ measures the after-minus-before change in Tobin's $q$ for treatment group firms, relative to control group firms.

\section{Data and summary statistics}

Testing our model requires firm-level stock ownership, accounting, delisting, and trading data. Each raises its own challenges in the Bulgarian context.

Overall sample. We obtain a list of all 1,040 Bulgarian companies that participated in mass privatization and were then listed on the Bulgarian Stock Exchange (BSE) in 1998 from the Center for Mass Privatization. Atanasov (2005) and Miller and Petranov (2000) provide details on the mass privatization process. Following the mass privatization auctions in 1998, more than $90 \%$ of all firms had a $20 \%+$ blockholder.

Share ownership. We obtain year-end shares outstanding, ownership of the largest shareholder, ownership of other $5 \%$ blockholders, and ownership by shareholder type (government, private companies, individuals, and financial institutions) for 1998 to 2003 for 1,021 of the 1,040 mass privatization firms from the Bulgarian Central Depository.

Delisting and financial data. We obtain listing and delisting information from the FSC. We exclude 190 firms which never traded or filed financial reports, and nine companies which were acquired or went bankrupt in 1998 and have no data available. The remaining 822 firms are required to file financial data annually in spreadsheet form, which we obtain. We go through a series of steps (details available from the authors) to extract data items from the spreadsheets and correct obvious data entry errors. In the end, we extract reasonably complete data for 738 of the 822 firms, for at least one year from 1999 to 2003. 
Stock prices. We obtain trade-by-trade volume and price data for 1999-2003 from the BSE. The market is thin with a mean (median) of 15 (3) trades per firm per year over this period, and some firms have zero trades. We collect by hand data on freezeout offers from news tapes provided by the BSE. These are available only beginning in 2001 .

Equity tunneling events. We trace equity tunneling events (dilution and delisting) over 1998-2003 for the 822 firms with ownership and delisting data. We define equity dilution as a firm issuing $20 \%$ or more new shares in a single year. Of the 822 initial post-privatization firms, 68 experience dilution only and 492 are delisted. Of the delisted firms, 60 experience dilution in one year followed by freezeout in the same or a subsequent year (if dilution and freezeout occur in the same year, we cannot tell which came first). Altogether, 560 of the 822 firms (68\%) experience an equity tunneling event. Firms that remain public also steadily transition away from having no majority owner. This pattern is consistent with Bebchuk's (1999) argument that dispersed ownership is unstable if private benefits of control are high. Table 3 shows the yearby-year number of equity tunneling events.

State-owned firms. We exclude firms with majority state ownership in our main results but include these firms in robustness checks. There are 124 such firms at year-end 1998, but only 13 at year-end 2001, largely due to the state selling its controlling stake as part of an ongoing privatization process.

\section{Dilution and freezeout: Pre- versus post-law differences}

In this section, we study how the 2002 legal change affect equity tunneling. Section 5.1 examines equity offerings. Section 5.2 examines freezeout offers. 


\subsection{Dilutive equity offerings}

In Table 4, we estimate minority shareholder participation in equity offerings using Equation (11). We construct the dilution measure 1- $\left(1-\alpha_{1}\right) /\left(1-\alpha_{0}\right)$ based on year-end ownership by the largest shareholder. We construct the equity increase measure EquityInc $=i /(1+i)$ based on year-end shares outstanding: $i=\left(\right.$ shares $_{\mathrm{t}}-$ shares $\left._{\mathrm{t}-1}\right) /$ shares $_{\mathrm{t}-1}$. We regress the dilution measure on EquityInc and an interaction term postlaw *EquityInc. We pool the pre- and post2002 observations to report an F-test for whether the pre- and post-2002 estimates of $(1-\mathrm{k})$ are statistically different.

The first two columns of Table 4 report regression results for the 153 firms which make large offerings (defined as a $20 \%$ or greater year-over-year increase in shares outstanding). The results are consistent with the law change greatly reducing minority shareholder dilution. Our pre-2002 estimate for $(1-k)$ is close to 1 . Thus, $k$ is roughly zero and minority shareholders are (on average) completely excluded from new equity issues. After 2002, $(1-k)$ is close to 0 , so $k$ $\approx 1$ and, on average, minority shareholders participate pro rata in equity offerings. This is consistent with the 2002 changes largely eliminating dilutive offerings, and companies issuing shares primarily to raise capital, rather than to dilute minority investors. ${ }^{5}$ Anecdotal evidence

\footnotetext{
${ }^{5}$ In robustness checks, we obtain similar results if we estimate separate regressions for the pre-law and post-law samples or use cutoff levels of a $50 \%$ or $100 \%$ increase in outstanding shares. We cannot determine whether controllers increased their stake between $t-1$ and $t$ by purchasing shares on the open market or through the equity issuance. This data limitation is unlikely to be significant because average annual share turnover for the firms in the dilution regressions is $5 \%$, while the average increase in number of shares is $400 \%$. Still, as a robustness check, we re-estimate the regressions with a conservative dilution measure which assumes that all traded shares during the year were purchased by the controlling shareholder. The pre-law estimate for $(1-k)$ becomes 0.6 (significant) and the post-law change is -0.85 (significant), which is consistent with the post-law change estimated in Table 5 . Another concern in interpreting Table 5 is whether different types of firms issue equity pre-2002 and post-2002. In unreported robustness checks, we address this concern by separating firms into three categories: firms that did not issue equity, firms that issued equity pre-2002, and firms that issued equity post-2002. We estimate multinomial logit models to determine whether these three groups differ in percent owned by the largest shareholder, percent owned by the state, and $\ln$ (market capitalization), and do not find significant post-law differences in which firms issue shares.
} 
supports the regression results. We are unaware of a single "genuine" equity offering (intended to raise capital, rather than dilute minority shareholders) by a Bulgarian firm prior to 2002 .

Genuine offerings begin to appear after the law change.

The last column of Table 4 reports results for a control group of 79 firms which delist first, and then engage in dilutive offerings. We observe these offerings because most delisted firms continue to use the Bulgarian Central Depository as a share registry after delisting. These 79 firms have a high estimated value of $(1-k)$, and thus negative estimated $k$. This indicates that in addition to the dilutive offering, the controllers buy additional shares from minority shareholders. The law change should not - and indeed does not - significantly affect the estimate of $(1-k)$, since these firms are not public and thus not subject to the new law. This is consistent with the law change - rather than some unobserved factor - causing the post-law decline in $(1-k)$ for public firms.

The degree of harm to minority shareholders from equity offerings involves a combination of exclusion from participation (1-k), offering size, and the offering price. Most offerings are very large, the number of outstanding shares more than doubles for 109 of the 128 prelaw offerings. The mean (median) increase is $400 \%(177 \%)$. We lack data on offer prices for most offerings. However, we are able to find a limited number of public announcements. For these, pre-law prices cluster at the minimum lawful price of 1 lev per share regardless of the market price of the shares. ${ }^{6}$

\footnotetext{
${ }^{6}$ For example, the shares of one of the most liquid companies on the BSE - Sofarma, AD traded at the beginning of December 2000 around $13 \mathrm{lev}$ per share. During that month, Sofarma announced an equity issue priced at 1 lev a share, which increased the number of shares outstanding by $536 \%$. We estimate $k=0.67$ for this issue; the controller's stake increased from $66 \%$ to $77 \%$.
} 


\subsection{Delistings}

About $60 \%(492 / 822)$ of the privatized firms with trading data were delisted in the prelaw period. Most of these firms (386 out of 492) do not trade during the three months before delisting date. They simply go dark, with no formal freezeout offer to minority shareholders. The remaining 106 firms have at least one trade in the three months before delisting, and therefore must make a tender offer for minority shares at a price no lower than the weighted average trading price of the shares over the three months before delisting.

At least 60 firms engage in dilutive offerings prior to delisting; the freezeout can then take place at a price already depressed by the dilutive offering. In Table 5, Panel A, we report seven representative examples of dilution followed by delisting. In each, minority shareholders either do not participate at all $(k=0)$ or participate minimally.

Some firms employ large block trades at low prices with related parties during the threemonth measurement period, to reduce the freezeout price. In Table 5, Panel B, we report seven examples of apparent manipulative block trades (at least 50 times average daily trading volume) in the three months before delisting. These large trades represent an average of $89 \%$ of trading volume during the three months preceding delisting and are at an average discount of $81 \%$ to the volume-weighted price of other trades during this period. The freezeout price will thus be at an average discount $d_{\text {freeze }}$ of $0.81 * 0.89=72 \%$ to the market price excluding these trades and an even larger discount to intrinsic value. Table 5 provides a rare glimpse of likely market manipulation in connection with a tender offer (Hermalin and Schwartz, 1996). We also see an important interaction - the effectiveness of a market price rule for freezeouts depends on legal control of dilution and of manipulative trades. 
Freezeout terms change dramatically after the 2002 legal changes. We identify 31 tender offers with offer prices over 2001-2003 using BSE news tapes. Of these, two firms have no trades in the three months before the offer. Table 6 provides summary data for these tender offers.

Pre-2002, offer premia over the minimum allowed price are small, and none of the ten initial offers are revised upwards. After the law change, the mean (median) final premium over the trade-volume-weighted average price for the last three months is $74 \%(42 \%)$. These premia compare favorably with the premia for going-private transactions in the United States (e.g. DeAngelo, DeAngelo, and Rice, 1984). Ten of the 21 post-law offers are revised upwards to secure minority shareholder and regulatory approval of the offer price. The post-law increases in mean and median premia are statistically significant.

The higher post-law premia understate the effect of the law change on freezeout outcomes. The premium is based on the pre-offer share price. Pre-law prices were sometimes explicitly depressed by dilutive offerings or manipulative block trades, and were also depressed by the risk of a future equity tunneling event. As we show below, valuation ratios for firms at high risk of equity tunneling increase post-law. Thus, post-law, the premium is higher, and the base price to which the premium applies is higher as well. Table 6 also reports the pre- and postlaw mean (median) ratio of offer price/sales and offer price/ book value. These measures reflect both the premium and the higher base price. The mean (median) final offer price/sales ratio quadruples, from $0.16(0.07)$ to $0.65(0.30)$, while mean (median) offer price/book doubles (quadruples). The mean rise in offer price/sales and the rise in both medians are statistically significant, despite small sample size. 
The higher postlaw offer price/sales and offer price/book ratios largely reflect higher offer prices relative to trading prices of shares, rather than higher trading prices. The final two rows of Table 6 report mean and median "market-adjusted" ratios. To compute the adjusted ratio, we divide offer price/sales (offer price/book) by the mean ratio of trading price/sales (trading price/book) for non-frozen-out firms in the freezeout year. The after-minus-before changes in the mean-adjusted ratios are, in effect, $\mathrm{DiD}$ estimates, where the control group is nonfrozen-out firms. We will underestimate the effect of the law change if the change results in higher share prices for the control group. The increases in market-adjusted ratios are very similar, in size and statistical significance, to the raw ratios.

\section{Firm characteristics and changes in profitability and equity valuation}

We next examine how the law change affects the profitability and valuations of highequity-tunneling risk firms, relative to low-equity-tunneling-risk firms. We first estimate each

firm's propensity to engage in dilution or delisting pre-law (Section 6.1). We then assess whether these tunneling propensities predict post-law change in ROA (Section 6.2), and Tobin's $q$ (Section 6.3).

\subsection{Estimates of equity tunneling propensities}

We estimate the probability that a firm will engage in dilution or delist during 1999-2001, based on the firm's financial and ownership characteristics. To reduce endogeneity issues, we use financial data from 1999, the first post-privatization year for which data is available. We measure ownership prior to the delisting (dilution) event, or at year-end 2001 if no delisting (dilution) occurs.

We estimate two propensity models, which differ in how we measure ownership. In both, we use the following financial variables: $\ln ($ sales $)$, leverage ((long-term debt + short-term 
debt)/total assets), exports/sales in 1996 (the last year with available data), operating margin, sales growth from 1998-1999, and a dummy variable for positive net income. In model (1) we control for ownership using the equity stake of the largest private blockholder, the difference between the ownership stake of the largest and the second-largest shareholder (see Laeven and Levine, 2007), and dummy variables for presence of minority state ownership and a majority private shareholder.

In model (2), we replace the ownership variables with the Shapley values of the largest private owner and of the state, which measure the likelihood that a shareholder will be pivotal in a voting contest (Milnor and Shapley, 1978; Shapiro and Shapley, 1978); and a "Shapley wedge" variable as a measure of the difference between the largest shareholder's voting control and economic ownership: Shapley wedge $=$ Shapley value/ownership stake of the largest private blockholder. ${ }^{7}$ We compute Shapley values using three blockholders and an ocean of other shareholders, where the third blockholder is the combined stake of all financial institutions (we have data on combined ownership by financial institutions, but no data on the stake of each institution). Laeven and Levine (2007) and Maury and Pajuste (2005) provide evidence on the influence of other blockholders, not only the largest holder.

Table 7 shows marginal effects from logit regressions of dilution and delisting propensities. In both models, the factors that predict delisting are quite different from those that predict dilution. For example, if we focus on sign rather than significance, larger firms and more

\footnotetext{
${ }^{7}$ For example, if a shareholder has $50 \%$ of the shares, it has $100 \%$ control, and will have Shapley wedge $=($ Shapley value $=1) /($ economic ownership $=0.5)=2$. The Shapley wedge value will rise from 1 for a small stake to 2 as ownership rises from 0 to $50 \%$, and will then decline toward 1 as the controller's stake rises toward $100 \%$. We use the Shapley wedge measure rather than the simple "wedge" variable used in other research (defined as the difference between fractional control rights and fractional economic rights) because Bulgaria has a one share, one vote regime, and few controllers use pyramids or cross-ownership, and thus the traditional "wedge" is on average small, with little variation across firms.
} 
leveraged firms are less (more) likely to be delisted (diluted), while profitable firms are more (less) likely to be delisted (diluted). We use the logit coefficients to estimate each firm's propensity to dilute and delist (the parameters tunprop $_{d}$ and tunprop $_{f}$ in Equation12). Delisting (dilution) propensity estimates using model (1) range from 0.04 to 0.98 (0.03 to 0.67$)$. As suggested by their different loadings on firm characteristics, the delisting and dilution propensities correlate negatively, at $-0.65(-0.53)$ for model 1 (model 2$)$. The two models produce similar propensity estimates - correlations between the estimates from the two models are 0.92 for delisting and 0.89 for dilution.

\subsection{Equity tunneling propensities and cash-flow tunneling}

The 2002 changes do not directly affect firm profitability or the availability of cash-flow tunneling. However, we hypothesize that the legal changes indirectly affect cash-flow tunneling, and therefore observed profitability, because controllers who would have previously engaged in equity tunneling choose to substitute into greater cash-flow tunneling. If so, then observed profitability should decline for firms at high risk of equity tunneling, relative to low-tunnelingrisk firms. We test this hypothesis in Table 8. We use firm-fixed-effects regressions to estimate model R1 of Equation (12) and examine after-minus-before law changes in ROA, measured as $\mathrm{EBIT}_{\mathrm{t}} /$ assets $_{\mathrm{t}-1}$, winsorized at $1 \%$ and $99 \%$. The coefficients of principal interest are on the interaction terms between the postlaw dummy and the delisting and dilution propensities.

We report results separately for propensity models (1) and (2). For both models and both propensities, the coefficients on the interactions between the propensities and the postlaw dummy are negative, statistically significant, and economically very large. For example, with propensity model (1) and full controls, a low-to-high change in delisting (dilution) propensity predicts a $0.19(0.22)$ decline in ROA, compared to a sample mean of 0.04 . A one standard 
deviation change in propensity to delist (dilute) predicts a $0.05(0.05)$ decline in ROA. Our results are consistent with controllers of high-equity-tunneling-risk firms sharply increasing their cash-flow tunneling after the law changes restrict equity tunneling.

Higher cash-flow tunneling is, of course, only one reason why the observed profitability of high-equity-tunneling-risk firms might decline, relative to low-risk firms. We cannot rule out the possibility that some set of firm characteristics is both associated with equity tunneling risk and predicts a decline in profitability after 2002 , for reasons unrelated to the law change. However, the propensities to delist and dilute load very differently on firm characteristics. Thus, for example, if larger firms become less profitable after 2002, this would, other things equal, predict a negative (positive) coefficient on dilution (delisting) propensity in Table 8. If firms which were more profitable pre-law declined in relative profitability post-law, this would predict a positive (negative) coefficient on dilution (delisting) propensity.

In unreported robustness checks, we obtain similar results if we: (i) use operating margin (EBIT/sales) as the dependent variable, instead of ROA; (ii) include state-controlled firms in the sample; (iii) limit the post-law period to 2002; (iv) exclude firms which change ownership from majority-state ownership to non-majority state ownership, or from no majority private owner to a majority private owner; (v) take logs of all continuous variables; and (vi) use the DiD approach discussed in Section 6.3 below. We also obtain consistent results with a combined measure of propensity to either delist or dilute.

In sum, we find a sharp decline in post-law profitability for high-equity-tunneling-risk firms, relative to low-risk firms, which is consistent with controllers of these firms engaging in greater cash-flow tunneling after the 2002 legal changes block the previously open road of equity tunneling. The decline in profitability for high-equity-tunneling-risk firms (whether or not due to 
higher cash-flow tunneling) makes all the more striking the results in the next section, where we find that the Tobin's $q$ of these firms rises significantly post-law.

\subsection{Equity tunneling propensities and firm valuation}

We next explore the association between equity tunneling risk and after-minus-before law changes in firm valuation, proxied by Tobin's $q$. We estimate Tobin's $q$ on a quarterly basis, similar to Kaplan and Zingales (1997), as (book value of assets + market value of equity - book value of equity)/(book value of assets). ${ }^{8}$ We use the volume-weighted average price for the quarter to measure market value of equity. ${ }^{9}$

In Table 9, we estimate model R2 of Equation (12) using a firm-fixed-effects specification, over 2000-2003, both with and without controls for profitability, leverage, and ownership. We exclude the fourth quarter of 2001 from the pre-law period, since the changes in securities law were then being debated in Parliament. The coefficients of principal interest are the interaction terms between the postlaw dummy and the delisting and dilution propensities. Assuming that the post-law relative decline in the profitability of high-equity-tunneling-risk firms reflects greater cash-flow tunneling, then regressions which omit the ROA control provide an estimate of the unconditional value effects of the law change, while regressions with this control provide an estimate holding cash-flow tunneling constant.

We find positive, economically large, and statistically significant coefficients on the interaction variables for both propensity measures across all specifications. The coefficients on

\footnotetext{
${ }^{8}$ An alternate definition of Tobin's $q$, also commonly used in governance research, is $q=$ (market value of equity + book value of long-term debt)/(book value of assets). This definition is not appropriate for Bulgaria because longterm debt markets are virtually nonexistent pre-2002, so firms rely for financing on equity and short-term debt (often accounts payable). Perhaps not coincidentally, since 2002, the Bulgarian long-term debt market has developed rapidly.

9 An event study is not feasible. As is often the case for legal reforms, it is difficult to pinpoint an exact event date (Bhagat and Romano, 2002). In addition, most Bulgarian firms trade once a month or less, so we cannot reliably estimate abnormal returns over a limited time period.
} 
the interaction variables are somewhat larger if we control for profitability, as expected given the results in Table 8 . To give a sense for economic magnitude, with propensity model (1) and no controls, a low-to-high change in propensity to delist (dilute) predicts an increase of $0.33(0.43)$ increase in Tobin's $q$, while a one-standard-deviation increase predicts a $0.08(0.10)$ increase. These are substantial compared to the pre-law mean Tobin's $q$ of 0.51 . The low pre-law mean, compared to US levels, is consistent with equity tunneling risk suppressing pre-law prices.

In unreported robustness checks, we obtain results similar to those in Table 9 if we: (i) use price/sales, price/earnings or market/book as the dependent variable; (ii) include statecontrolled firms in the sample; (iii) exclude firms that change ownership from majority-state ownership to non-majority state ownership, or from no majority private owner to a majority private owner; or (iv) use a combined measure of propensity to either delist or dilute. We also estimate a two-stage model, to address possible endogeneity between Tobin's $q$ and ROA. In the first stage we regress Tobin's $q$ on ROA using pre-law data. In the second stage, we use this model to predict Tobin's $q$ across the whole sample, and use the difference between actual and predicted $q$ as the dependent variable in regressions otherwise similar to Table 9. The results from the two-stage estimation are qualitatively similar to Table $9 .{ }^{10}$

As an additional robustness check on our results, we use a difference-in-differences approach, in which we divide firms into high and low-equity-tunneling-risk groups and measure post-law changes in the valuation of high-risk firms, relative to low-risk firms. We use two

\footnotetext{
${ }^{10}$ To further confirm robustness, we run a variety of additional specifications. First, instead of logit propensity regressions, we use linear probability (OLS) or probit. Second, we run the firm value regressions with Tobin's $q$ and propensities winsorized at $1 \% / 99 \%$ or $5 \% / 95 \%$, and with both Tobin's q and continuous independent variables in logs. Third, we change the pre- and post-law estimation windows - include 2001-Q4 in the prelaw period, or omit 2002-Q1 from the post-law period. Fourth, we use operating margin instead of ROA to control for profitability or include a battery of control variables (ln(sales), sales growth, and sales/assets; interactions between the postlaw dummy and the control variables. Results from all variations are consistent with those reported in Table 10.
} 
alternative control groups. The first uses ownership by the largest holder to proxy for equity tunneling risk. Firms with no $20 \%$ blockholder form the low-equity-tunneling-risk group. In contrast, if a firm has a large private blockholder, this holder often has both the ability and the incentive to engage in equity tunneling; hence these firms should have a high probability of tunneling. We create two treatment groups - firms with a 50\% private blockholder, who clearly has the ability to cause tunneling to occur, and firms with a $20-50 \%$ blockholder, who will often have this ability.

The second approach is based on the propensity analysis. The treatment group is firms which have above median propensity to either dilute or to delist using propensity model 1 from Table 7. The control group is firms which are at below-median risk for both delisting and dilution.

Table 10 reports firm-fixed-effects DiD results for both sets of control and treatment groups. The variables of interest are the interaction terms between the postlaw dummy and the treatment group dummy variables, which capture the post-law change in Tobin's $q$ for these firms, relative to the control group. Tobin's $q$ rises significantly post-law for the ownershipbased treatment groups ( $50 \%$ control and $20-50 \%$ control), as well as for the propensity-based treatment group, both with and without controlling for profitability.

Last, we present visually the changes in $q$ around the 2002 legal changes for groups of firms at different risk of tunneling. Sample size is limited, because we use a balanced panel of firms with non-missing Tobin's $q$ ratios for all eight quarters in the 2001-2002 period. We separate the sample into high-tunneling-risk firms versus low-risk firms, using the same ownership and tunneling propensity approaches as in Table 10. For each group, we compute mean Tobin's $q$ for each quarter in 2001-2002. We then compute percentage changes in these 
mean ratios, using the first quarter of 2001 as the base period. Figure 1 shows the percentage change for high-equity-tunneling-risk firms, minus the percentage change for low-equitytunneling-risk firms. The mean Tobin's $q$ for high-equity-tunneling-risk firms jumps relative to low-risk firms in Q1 2002 by 40\% with the ownership based control group, and 80\% with the propensity based control group. Thus, the rise in valuation ratios for high-equity-tunneling-risk firms is concentrated in the quarter when the legal reforms become effective.

A non-causal story which explains our results is hard to come by. One would have to posit that one set of firm-level characteristics is correlated with delisting risk, another quite different set is correlated with dilution risk (the two sets load quite differently on factors such as size, profitability, and ownership in propensity logit regressions). Both sets of firm characteristics have to predict lower post-law profitability yet dramatically higher post-law share prices, at the precise time the anti-equity-tunneling law takes effect and dilutive offerings and below-market freezeouts stop, for a reason other than the decline in equity tunneling risk.

\section{Summary and implications}

This paper examines how law can control two forms of equity tunneling, dilutive equity offerings and freezeouts; how equity tunneling risk can affect firms' market values; and the potential for controllers to substitute one type of tunneling for another. We first develop a partial equilibrium model which allows for three types of tunneling - cash-flow tunneling, dilution, and freezeout. In the model, investors rationally discount the prices they pay for shares, and may rationally not participate in dilutive share offerings if they lack legal protection against freezeouts. We test the model's predictions with data from Bulgaria. A 2002 change in Bulgarian law increases protection against dilutive offerings and freezeouts and thus provides a natural experiment. After the law change, dilutive offerings, which had been common, basically 
cease. Below-market freezeouts and going dark transactions also cease; the freezeouts which occur are at premiums to market value, and freezeout offer price/sales ratios roughly quadruple.

The law change also has a large effect on share values. Tobin's $q$ levels for high- equitytunneling risk firms rise sharply, relative to low-risk firms. These increases occur even though the profitability of high-equity-tunneling-risk firms drops post-law - which we interpret as evidence of controllers substituting from equity tunneling into greater cash-flow tunneling.

We thus provide evidence for an important channel through which legal protection of shareholder rights affects financial market outcomes - by controlling equity tunneling. We also provide evidence on substitution by controlling shareholders between cash-flow and equity tunneling. Our results have implications for asset pricing in emerging markets. We find evidence that equity tunneling risk varies widely between firms in Bulgaria, and that Bulgarian investors consider this risk and update their valuation estimates when legal rules change. Equity tunneling risk thus emerges as an important factor in explaining cross-sectional and time-series variation in equity prices. Our firm-level evidence of links between specific laws and specific forms of tunneling, and between tunneling risk and market prices, complements the crosscountry research on the relationship between legal protections and capital market development. 


\section{Appendix. Model proofs and extensions}

\section{A.1. Proofs}

\section{A.1.1. Proof of Equation (4):}

The minority shareholders initially hold $\left(1-\alpha_{0}\right)$ shares, each worth $V_{n o-e q}$ without equity tunneling. The dilutive issuance causes minority shareholders to lose a proportion $d_{\text {dilut }} \frac{i}{1+i}$ of this per-share value. They also purchase a fraction $\left(1-\alpha_{0}\right)^{*} k$ of the newly issued shares at the discounted offering price and make a profit on these shares (as a proportion of $\left.\left(1-\alpha_{0}\right) * V_{n o-e q}\right)$ equal to (post-dilution per-share value - price paid), for a total gain of:

$$
k^{*} i\left[1-d_{\text {dilut }} \frac{i}{1+i}-\left(1-d_{\text {dilut }}\right)\right]=k^{*} d_{\text {dilut }} \frac{i}{1+i}
$$

Equation (4) equals the loss on original holdings minus the gain on newly acquired shares.

\section{A.1.2. Proof of Equation (6)}

Prior to the freezeout, the minority shareholders own $\left(1-\alpha_{1}\right)$ shares which are each worth $V_{\text {no-freeze }}$ without a freezeout. The minority shareholders will lose a fraction $d_{\text {freeze }}$ of this value. Equation (6) follows directly after plugging in post dilution ownership (1- $\left.\alpha_{1}\right)$ and post-dilution value $V_{\text {no-freeze }}$ from Equations (2) and (3) respectively.

\section{A.1.3. Proof of Equation (11)}

Start with Equation (2) for minority ownership after dilution $\left(1-\alpha_{1}\right)$, and divide both sides by (1 $\left.-\alpha_{0}\right)$

$$
\frac{\left(1-\alpha_{1}\right)}{\left(1-\alpha_{0}\right)}=\frac{\left[1+k^{*} i\right]}{(1+i)}
$$

Now multiply by -1 and add 1 to both sides to reach: 


$$
1-\frac{\left(1-\alpha_{1}\right)}{\left(1-\alpha_{0}\right)}=1-\frac{\left[1+k^{*} i\right]}{(1+i)}
$$

Equation (11) is then straightforward to derive after rearranging terms.

\section{A.2. Interaction between dilution and freezeout}

We examine here the interaction between minority shareholder willingness to purchase shares in an offering and freezeout risk. Assume that minority shareholders have preemptive rights to purchase shares in an equity offering pro-rata, but freezeout rules are weak and let minority shareholders be frozen out at a large discount $d_{\text {freeze }}$.

If the risk of a freezeout at a discount is high enough, minority shareholders will not exercise their preemptive rights for a discounted share offering, because the near-term gain by buying shares for less than market value will be offset by the expected loss in a future freezeout. Minority shareholders will rationally exercise preemptive rights only if the offering price is less than the expected share value after the dilutive offering, taking into account the risk of

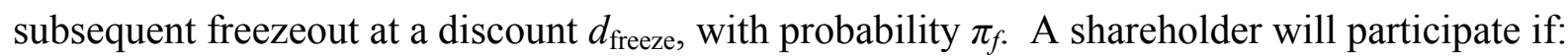

$$
\left(1-d_{\text {dilut }}\right) \leq \frac{1+i\left(1-d_{\text {dilut }}\right)}{1+i}\left(1-\pi_{f} d_{\text {freeze }}\right)
$$

If $d_{\text {freeze }}$ and $\pi_{f}$ are sufficiently high, preemptive rights will not prevent dilutive offerings. Thus, protections from equity dilution will work only in conjunction with protections against freezeout. Anti-freezeout statutes thus play a dual role in reducing the effect of equity tunneling. They directly reduce expropriation in freezeouts and allow minority shareholders to rationally exercise preemptive rights, thus limiting equity dilution. 


\section{References}

Atanasov, V., 2005. How much value can blockholders tunnel? Evidence from the Bulgarian mass privatization auctions. Journal of Financial Economics76, 191-234.

Atanasov, V., Black, B., Ciccotello, C., 2009. Unbundling and measuring tunneling. Unpublished working paper. Available at http://ssrn.com/abstract=1030529.

Atanasov, V., Durnev, A., Fauver, L., Litvak, K., 2008. The anatomy of preemptive rights and other antidilution provisions in emerging markets. Unpublished working paper.

Baek, J. S., Kang, J. K., Lee, I., 2006. Business groups and tunneling: Evidence from private securities offerings by Korean Chaebols. Journal of Finance 61, 2415-2449.

Bates, T., Lemmon, M., Linck, J., 2006. Shareholder wealth effects and bid negotiation in freezeout deals: Are minority shareholders left out in the cold? Journal of Financial Economics 81, 681-708.

Bebchuk, L., 1999. A rent-protection theory of corporate ownership and control. NBER Working Paper No. 7203. Available at http://ssrn.com/abstract=203110.

Beck, T., Demirguc-Kunt, A., Levine, R., 2005. Law and firms' access to finance. American Law and Economics Review 7, 211-252.

Bertrand, M., Mehta, P., Mullainathan, S., 2002. Ferreting out tunneling: An application to Indian business groups. Quarterly Journal of Economics 117, 121-148.

Bertrand, M., Duflo, E., Mullainathan, S., 2004. How much should we trust Differences-in-Differences estimates?. Quarterly Journal of Economics 119, 249-275.

Bhagat, S., Romano, R., 2002. Event Studies and the Law: Part I: Technique and Corporate Litigation. American Law and Economics Review 4, 141-168.

Bhattacharya, U., Daouk, H., 2002. The world price of insider trading. Journal of Finance 57, 75-108.

Black, B., Kraakman, R., Tarassova, A., 2000. Russian privatization and corporate governance: What went wrong. Stanford Law Review 52, 1731-1808.

Black, B., 2001. The corporate governance behavior and market value of Russian firms. Emerging Markets Review 2, 89-108.

Black, B., 2001a. The legal and institutional preconditions for strong securities markets. UCLA Law Review 48, 781-858.

Burkart, M., Gromb, D., Panunzi, F., 1998. Why higher takeover premia protect minority shareholders. Journal of Political Economy, 106, 172-204.

Carvalhal-da-Silva, A., Subramanyam, A. 2007. Dual-class premium, corporate governance, and the mandatory bid rule: Evidence from the Brazilian stock market. Journal of Corporate Finance 13, $1-24$.

Coase, R., 1960. The problem of social cost. Journal of Law and Economics 3, 1-44.

DeAngelo, H., DeAngelo, L., Rice, E., 1984. Going private: Minority freezeouts and stockholder wealth. Journal of Law and Economics 27, 367-401.

Doidge, C., Karolyi, G. A., Stulz, R., 2007. Why do countries matter so much for corporate governance?. Journal of Financial Economics 86, 1-39.

Djankov, S, La Porta, R., Lopez-de-Silanes, F., Shliefer, A., 2008. The law and economics of self-dealing. Journal of Financial Economics 88, 430-465. 
Durnev, A., Kim, E. H., 2005. To steal or not to steal: firm attributes, legal environment, and valuation. Journal of Finance 60, 1461-1493.

Dyck, A., Zingales, L., 2004. Private benefits of control: An international comparison. Journal of Finance 59, 537-600.

Friedman, E., Johnson, S., Mitton, T., 2003. Propping and tunneling. Journal of Comparative Economics $31,732-750$.

Gilson, R., Gordon, J., 2003. Controlling controlling shareholders. University of Pennsylvania Law Review 152, 785-850.

Glaeser, E., Johnson, S., Shleifer, A., 2001. Coase versus the Coasians, Quarterly Journal of Economics 116, 853-899.

Hermalin, B., Schwartz, A., 1996. Buyouts in large companies. Journal of Legal Studies 25, 351-370.

Himmelberg, C.., Hubbard, R. G., Love, I., 2002. Investor protection, ownership, and the cost of capital. Unpublished working paper. Available at http://ssrn.com/abstract=303969.

Jiang, G., Lee, C., Yue, H., 2008. Tunneling in China: The remarkable case of inter-corporate loans. Unpublished working paper. Available at http://ssrn.com/abstract=861445.

Johnson, S., La Porta, R., Lopez-de-Silanes, F., Shleifer, A., 2000. Tunneling. American Economic Review 90, 22-27.

Kang, J. K., Stulz, R., 1997. Why is there a home bias? An analysis of foreign portfolio equity ownership in Japan. Journal of Financial Economic, 46, 3-28.

Kaplan, S., Zingales, L., 1997. Do investment-cash flow sensitivities provide useful measures of financing constraints?. Quarterly Journal of Economics 112, 169-215.

Laeven, L., Levine, R., 2007. Complex ownership structures and corporate valuations. Review of Financial Studies 21, 579-604.

Laeven, L., Woodruff, C., 2007. The quality of the legal system, firm ownership, and firm size. Review of Economics and Statistics 89, 601-614.

La Porta, R., Lopez-de-Silanes, F., Shleifer, A., Vishny, R., 1997. Legal determinants of external finance. Journal of Finance 52, 1131-1150.

La Porta, R., Lopez-de-Silanes, F., Shleifer, A., Vishny, R., 1998. Law and finance. Journal of Political Economy 106, 1113-1155.

La Porta, R., Lopez-de-Silanes, F., Shleifer, A., Vishny, R., 2002. Investor protection and corporate valuation. Journal of Finance 57, 1147-1170.

La Porta, R., Lopez-de-Silanes, F., Shleifer, A., 2006. What works in securities laws? Journal of Finance 61, 1-32.

Lerner, J., Schoar, A., 2005. Does legal enforcement affect financial transactions? The contractual channel in private equity. Quarterly Journal of Economics 120, 223-246.

Leuz, C., Triantis, A., Wang, T., 2008. Why do firms go dark? Causes and economic consequences of voluntary SEC deregistrations. Journal of Accounting and Economics 45, 181-208.

Marosi, A., Massoud, N., 2007. Why Do Firms Go Dark?, Journal of Financial and Quantitative Analysis 42, 421-442.

Maury, B., Pajuste, A., 2005. Large Shareholders and Firm Value. Journal of Banking and Finance 29, 1813-1834. 
Miller, J., Petranov, S., 2000. The first wave of mass privatization in Bulgaria and its immediate aftermath. Economics of Transition 8, 225-250.

Milnor, J., Shapley, L., 1978. Value of large games II: Oceanic games. Mathematics of Operations Research 3, 290-307.

Nenova, T., 2005. Control values and changes in corporate law in Brazil. Latin American Business Review 6, 1-37.

Qian, J., Strahan, P., 2007. How laws and institutions shape financial contracts: The case of bank loans. Journal of Finance 62, 2803-2834.

Shapiro, N., Shapley, L., 1978. Value of large games I: A limit theorem. Mathematics of Operations Research 3, 1-9.

Shleifer, A., Wolfenzon, D., 2002. Investor protection and equity markets. Journal of Financial Economics 66, 3-27. 


\section{Table 1 \\ Comparative Statics and Numerical Example}

Panel A shows the expected sign of the marginal effect of the six model parameters (assuming a dilutive offering is large, $\mathrm{i} /(\mathrm{i}+1) \sim 1)$ on observed return on assets $\left(R O A_{o b s}\right)$ and observed Tobin's $q\left(q_{o b s}\right)$ for all-equity firm. Observed return on assets $R O A_{o b s}=$ Earnings/Assets. $q_{o b s}=$ (market value of equity)/Assets. $d_{c f}=$ fraction of (unobserved) actual earnings that is diverted via cash-flow tunneling. $d_{\text {dilut }}=$ fractional discount at which new shares are issued, relative to pre-dilution firm value. $\pi_{d}$ = probability of dilutive offering. $k=$ fractional participation of minority shareholders in an equity offering. $d_{\text {freeze }}=$ fractional discount at which minority shares are acquired, relative to prefreezeout firm value. $\pi_{f}=$ probability of freezeout, given that dilution has already occurred. Panel B provides a numerical example of how a shock to tunneling parameters affects observed ROA and observed Tobin's $q$ for two hypothetical companies $-\mathrm{A}$ and B. Both companies have cost of capital $r=R O A_{\text {no-tun }}=10 \% ; d_{\text {dilut }}=d_{\text {freeze }}=0.6 ; k=$ 0 . Company $\mathrm{A}$ has high equity tunneling risk $\left(\pi_{d, A}=\pi_{f, A}=0.75\right)$. Company $\mathrm{B}$ has no equity tunneling risk $\left(\pi_{d, B}=\right.$ $\left.\pi_{f, B}=0\right)$. Company A originally does not engage in cash-flow tunneling $\left(d_{c f, A}=0\right)$, while Company B has $d_{c f, B}=$ 0.25 . A change in law causes $k$ to increase from 0 to 1 , and $d_{\text {freeze }}$ to drop from 0.6 to 0 . In response, Company A's controller increases $d_{c f, A}$ increases from 0 to 0.25 , while Company B increases $d_{c f, B}$ from 0.25 to 0.35 .

Panel A. Predicted Marginal Effects (see Proposition 2)

\begin{tabular}{lcccccc}
\hline & $d_{c f}$ & $d_{\text {dilut }}$ & $\pi_{d}$ & $k$ & $d_{\text {freeze }}$ & $\pi_{f}$ \\
\hline ROA $A_{\text {obs }}$ & - & 0 & 0 & 0 & 0 & 0 \\
$q_{\text {obs }}$ & - & - & - & + & - & - \\
\hline
\end{tabular}

Panel B. Numerical Example of Tunneling Shock

\begin{tabular}{lrrrrrr}
\hline & \multicolumn{3}{c}{ Firm A } & \multicolumn{3}{c}{ Firm B } \\
\cline { 2 - 7 } & Pre & Post & Change \% & Pre & Post & Change \% \\
\hline$R O A_{\text {obs }}$ & $10.0 \%$ & $7.5 \%$ & $-25 \%$ & $7.5 \%$ & $6.5 \%$ & $-15 \%$ \\
$q_{\text {obs }}$ & 0.48 & 0.75 & $55 \%$ & 0.75 & 0.65 & $-13 \%$ \\
\hline
\end{tabular}


Table 2

\section{Changes in Bulgarian Securities and Tax Law in 2002}

This table summarizes the principal 2002 changes to Bulgarian securities law and tax law. The changes to the securities law were introduced to Parliament by the Bulgarian government on December 14, 2001. The first draft of the law was approved by Parliament on February 14, 2002. The final version of the law was accepted by Parliament on June 6, 2002, and became effective on June 21, 2002. However, due to the efforts of the Financial Supervision Commission, firms were effectively subject to the new freezeout rules from the beginning of 2002 .

\begin{tabular}{|c|c|c|}
\hline Statute & Pre-2002 & 2002 \\
\hline $\begin{array}{l}\text { Preemptive } \\
\text { Rights }\end{array}$ & $\begin{array}{l}\text { Minority shareholders can } \\
\text { participate in new equity offerings. } \\
\text { If they do not participate, the } \\
\text { controlling shareholder can } \\
\text { purchase all unsubscribed shares. }\end{array}$ & $\begin{array}{l}\text { 1. Warrants are required to be issued for any capital } \\
\text { increase-one warrant for each share. } \\
\text { 2. Warrants are exercisable for a period of at least } 1 \text { month, } \\
\text { and are traded on the BSE. }\end{array}$ \\
\hline $\begin{array}{l}\text { Freezeout and } \\
\text { Delisting Rules }\end{array}$ & $\begin{array}{l}\text { In a freezeout transaction, a } \\
\text { controlling shareholder should offer } \\
\text { at least the weighted-average share } \\
\text { price from the last three months of } \\
\text { trading. Delisting without freezeout } \\
\text { is allowed if no trading within last } 3 \\
\text { months. }\end{array}$ & $\begin{array}{l}\text { 1. A controlling shareholder must make a tender offer for all } \\
\text { remaining shareholders when reaching } 50 \%, 67 \% \text {, and } \\
90 \% \text { ownership in the firm. A controlling shareholder can } \\
\text { initiate a freezeout only after reaching } 90 \% \text {. } \\
\text { 2. Minority shareholders should receive a fair price for their } \\
\text { shares in tender offers and going-private transactions. A } \\
\text { fair price is computed using discounted cash flow and } \\
\text { comparable company multiples valuation methods and is } \\
\text { compared to the average stock price for the last three } \\
\text { months, excluding block trades. Minority shareholders } \\
\text { should receive the higher of the two prices. } \\
\text { 3. A majority of minority shareholders has to approve going- } \\
\text { private transactions. } \\
\text { 4. The FSC has to evaluate the price in going-private } \\
\text { transactions and approve tender offers only if they meet } \\
\text { the "fair value" requirements. }\end{array}$ \\
\hline Tax Changes & $\begin{array}{l}\text { Capital gains and interest income } \\
\text { are taxed as regular income up to } \\
40 \% \text { marginal tax rate. Corporate } \\
\text { profits are taxed up to } 40 \%\end{array}$ & $\begin{array}{l}\text { 1. Tax rate on interest income from bank deposits and } \\
\text { publicly traded bonds, and capital gains from publicly } \\
\text { traded securities is set to } 0 \% \text {. } \\
\text { 2. Tax rate on corporate profits is reduced to } 22.5 \%\end{array}$ \\
\hline
\end{tabular}


Table 3

\section{Equity Tunneling Events across Time}

Yearly number of delistings (number of these involving a formal freezeout tender offer) and dilutive equity issues, proxied by a $20 \%$ year-over-year increase in outstanding shares (100\% increase) for the 822 Bulgarian firms which participated in the mass privatization process and have ownership and delisting data. The data for delistings ends in 2002, while the equity issue data includes 2003. Formal freezeout offers are offers announced on the BSE online news system.

\begin{tabular}{ccc}
\hline Year & $\begin{array}{c}\text { Delistings } \\
\text { (formal freezeout offers) }\end{array}$ & $\begin{array}{c}\text { Equity Issues } \geq 20 \% \\
(\geq 100 \%)\end{array}$ \\
\hline 1999 & 4 (n.a.) & $72(63)$ \\
2000 & $358($ n.a. $)$ & $36(31)$ \\
2001 & $130(10)$ & $20(15)$ \\
2002 & $45(17)$ & $9(6)$ \\
2003 & n.a. (4) & $16(9)$ \\
\hline
\end{tabular}


Table 4

\section{Dilution and Equity Issuance}

Equity offerings by listed and formerly listed Bulgarian firms that result in at least a $20 \%$ increase in shares outstanding during 1999-2003. The dependent variable is minority shareholder dilution, defined as $\left(1-\left(1-a_{1}\right) /(1-\right.$ $\left.a_{0}\right)$ ), where $a_{1}$ and $a_{0}$ are the fractional ownership by the largest owner at year end after and before the equity issuance. Listed firms are publicly-traded in the year of dilution. Delisted firms are firms which delist before the year of dilution, but continue to use the Bulgarian Central Depository as a share registry. We define the increase in equity capital as EquityInc $=i /(1+i)$, where $i=\left(\right.$ shares $_{l}$ - shares $\left._{0}\right) /$ shares $_{l}$ and shares ${ }_{l}\left(\right.$ shares $\left._{0}\right)$ is shares outstanding at the end of the year after (before) the offering. We regress minority shareholder dilution on EquityInc, EquityInc*postlaw dummy ( $=1$ for offerings during 2002 and 2003, 0 otherwise), and controls. The coefficient on EquityInc provides an estimate of $(1-k)$, which is a measure of the exclusion of minority shareholders from an equity offering ) pre-2002. The coefficient on EquityInc*postlaw is an estimate of the post-2002 change in (1-k). The control variables in Model 1 and 2 are $\alpha_{0}$, stateown fraction (fractional state ownership prior to the offering), and market capitalization (number of pre-offering shares times share price at the end of the pre-offering year, in millions of Bulgarian lev). Shareholder stakes and number of shares are measured at year-end. $t$-statistics, using White's robust standard errors, are in parenthesis. ${ }^{*}, * *, * * *$ denote significance at $10 \%, 5 \%$, and $1 \%$ level, respectively. Significant results, at $5 \%$ level or better, are in boldface.

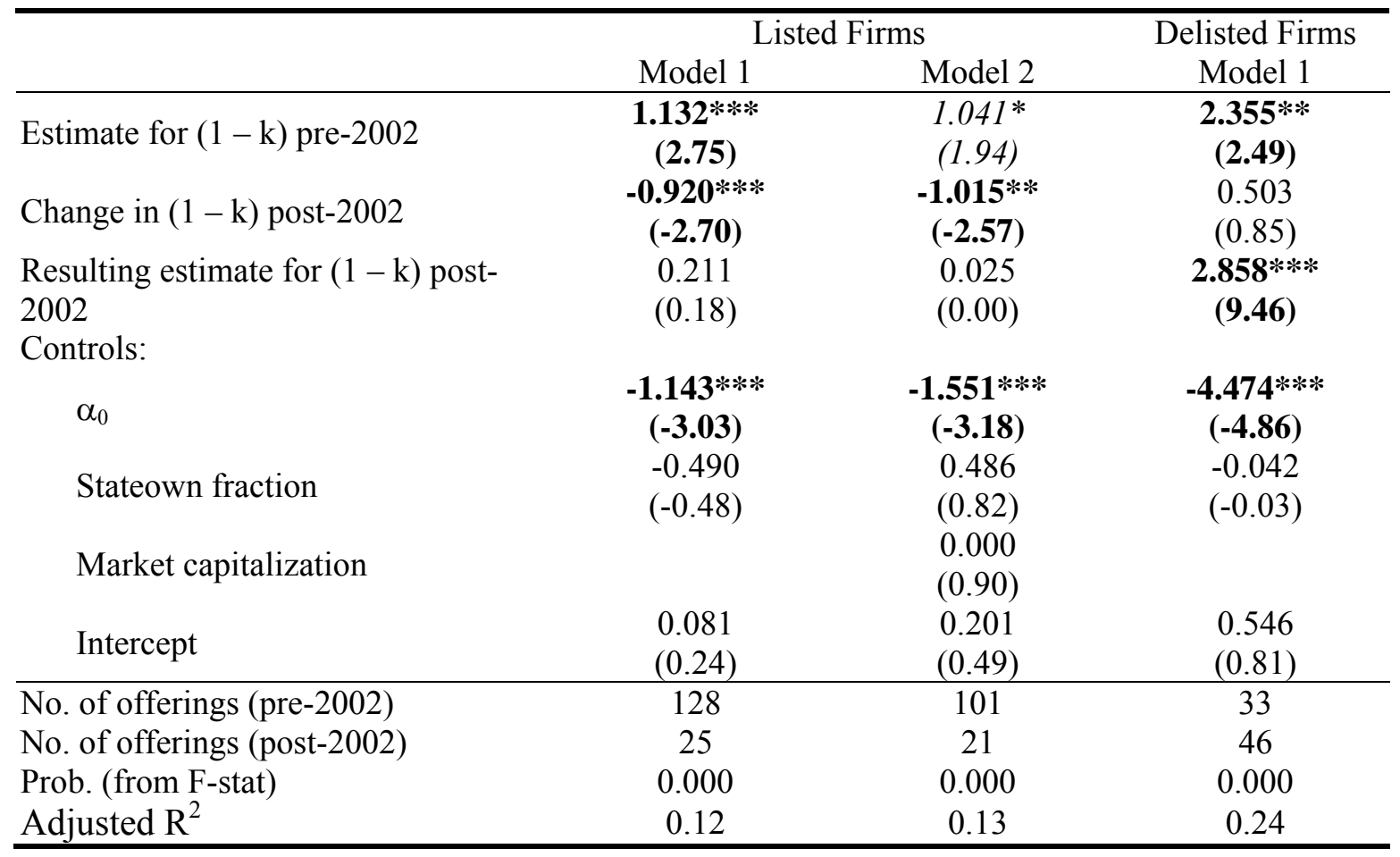


Table 5

\section{Examples of Equity Tunneling}

Representative examples of companies listed on the BSE that engage in equity tunneling. Panel A includes firms that first dilute minority shareholders and then delist prior to 2002. The coefficient $i$ equals the fractional increase in shares outstanding, $\alpha_{0}\left(\alpha_{1}\right)$ is the percentage ownership of the largest shareholder at the end of the year before the dilution year (the dilution year), $k$ is the estimated proportional participation of minority shareholders in the new issue, computed using Equation 11. We identify 60 firms which dilute in year $t$ and delist in the same or a later year. Panel B includes companies with large trades (50+ times daily trading volume) within three months before delisting, identified from BSE tapes. The pre-trade price range is taken over the three months before the last trade. The discount is computed as (weighted average price of other trades - price of block trade)/(weighted average price of other trades $)$. Weight of large trade $=($ size of trade $) /$ sum(all trades during three months preceding delisting $)$.

Panel A. Examples of Dilution Followed by Delisting

\begin{tabular}{lcccccc}
\hline Firm Name & $\begin{array}{c}\text { Dilution } \\
\text { Year }\end{array}$ & $\begin{array}{c}\text { Delisting } \\
\text { Year }\end{array}$ & $\boldsymbol{i}$ & $\boldsymbol{\alpha}_{0}$ & $\boldsymbol{\alpha}_{1}$ & $\boldsymbol{k}$ \\
\hline Balkan & 2000 & 2000 & 0.77 & $60.0 \%$ & $77.7 \%$ & 0.00 \\
Galko & 2000 & 2000 & 1.69 & $68.0 \%$ & $88.1 \%$ & 0.00 \\
Agropolihim & 2000 & 2001 & 5.07 & $63.0 \%$ & $93.9 \%$ & 0.00 \\
Shvedski Kibrit & 1999 & 2000 & 17.56 & $58.0 \%$ & $95.2 \%$ & 0.06 \\
Himatech & 2001 & 2001 & 2.00 & $27.4 \%$ & $66.4 \%$ & 0.19 \\
Dunav-57 & 1999 & 2000 & 3.12 & $48.0 \%$ & $80.2 \%$ & 0.18 \\
Sofia Princess Hotel & 1999 & 2001 & 1.85 & $60.0 \%$ & $86.0 \%$ & 0.00 \\
\hline
\end{tabular}

Panel B. Examples of Possible Use of Wash Trades to Reduce Delisting Price

\begin{tabular}{|c|c|c|c|c|c|c|}
\hline Firm Name & Trade date & Delisting date & $\begin{array}{c}\text { Pre-Trade } \\
\text { Price Range }\end{array}$ & $\begin{array}{c}\text { Price of } \\
\text { large } \\
\text { trade }\end{array}$ & $\begin{array}{l}\text { Discount of } \\
\text { large trade }\end{array}$ & $\begin{array}{l}\text { Weight of } \\
\text { large trade }\end{array}$ \\
\hline Plastimo & 4 Apr 2000 & 5 Jul 2000 & $5.00-8.00$ & 1.00 & 0.857 & 0.663 \\
\hline Preslav-AH & 19 May 2000 & 25 May 2000 & $2.68-3.51$ & 1.05 & 0.610 & 0.945 \\
\hline Sintermat & $4-6$ Oct 2000 & 29 Nov 2000 & $11.99-13.00$ & 2.50 & 0.790 & 0.952 \\
\hline Ropotamo & 9 Nov 2000 & 10 Jan 2001 & $13.66-20.70$ & 1.12 & 0.943 & 0.971 \\
\hline Loviko Chirpan & 15 Mar 2000 & 8 Jun 2000 & $10.00-10.00$ & 4.16 & 0.584 & 0.981 \\
\hline Himatech & 14 Aug 2001 & 4 Sep 2001 & $10.00-10.00$ & 1.10 & 0.890 & 0.762 \\
\hline General Ganetzki & 1 Oct 2001 & 15 Dec 2001 & $4.00-4.00$ & 0.12 & 0.970 & 0.938 \\
\hline Average: & & & & & 0.806 & $\mathbf{0 . 8 8 7}$ \\
\hline
\end{tabular}


Table 6

Freezeout Tender Offers Before and After 2002 Law Changes

Premia and offer/sales ratios for sample of 31 freezeout tender offers over 2001-2003, identified from BSE news tapes. Market price is trade-volume-weighted average trading price for the three months before the announcement. Premium $=($ offer price - market price $) /($ market price $)$. Offer price $/$ sales $=($ offer price $) /($ sales in year before tender offer). Offer price/book = (offer price)/(book value per share at end of year before tender offer). To compute market-adjusted ratios, we divide offer price/sales (offer price/book) for each freezeout offer by the mean ratio of trading price/sales (trading price/book) for non-frozen-out firms in the freezeout year. $t$-statistics for means and zstatistics for medians are in parentheses. *,**,*** denote significance at $10 \%, 5 \%$, and $1 \%$ level, respectively. Significant results, at $5 \%$ level or better, are in boldface. Marginally significant results $(\mathrm{P}<.10)$ are indicated with italics.

\begin{tabular}{|c|c|c|c|}
\hline $\begin{array}{c}\text { Characteristics } \\
\end{array}$ & Before 2002 Law & After 2002 Law & $\begin{array}{c}\text { Z-value (post-law - pre- } \\
\text { law difference) }\end{array}$ \\
\hline \multicolumn{4}{|l|}{ Summary Statistics of Tender Offers } \\
\hline Number of tender offers & 10 & 21 & \\
\hline $\begin{array}{l}\text { Offers for firms with trading in } 3 \text { months } \\
\text { before offer }\end{array}$ & 9 & 20 & \\
\hline $\begin{array}{l}\text { Average premium to market price for initial } \\
\text { tender offers }\end{array}$ & $\begin{array}{l}0.121 \\
(0.85)\end{array}$ & $\begin{array}{c}0.349 * * * \\
(2.85)\end{array}$ & 1.10 \\
\hline $\begin{array}{l}\text { Median premium to market price for initial } \\
\text { offers }\end{array}$ & $\begin{array}{l}0.001 \\
(1.55)\end{array}$ & $\begin{array}{c}0.166 * * * \\
(3.31)\end{array}$ & 1.42 \\
\hline $\begin{array}{l}\text { Number of offer prices that are revised } \\
\text { upwards }\end{array}$ & 0 & 10 & \\
\hline Average premium for final offers & $\begin{array}{l}0.121 \\
(0.85)\end{array}$ & $\begin{array}{l}0.740 * * * \\
(3.44)\end{array}$ & $1.84^{*}$ \\
\hline Median premium for final offers & $\begin{array}{l}0.001 \\
(1.55)\end{array}$ & $\begin{array}{c}0.416 * * * \\
(3.45)\end{array}$ & $2.17 * *$ \\
\hline \multicolumn{4}{|l|}{ Raw Offer Price Ratios } \\
\hline Mean (median) Final Offer Price/Sales & $\begin{array}{c}0.150 \\
(0.076)\end{array}$ & $\begin{array}{c}0.649 \\
(0.296)\end{array}$ & $\begin{array}{c}2.01 * * \\
(2.80)^{* * *}\end{array}$ \\
\hline Mean (median) Final Offer Price/Book & $\begin{array}{c}0.360 \\
(0.123)\end{array}$ & $\begin{array}{c}0.744 \\
(0.487)\end{array}$ & $\begin{array}{c}0.94 \\
(1.98) *\end{array}$ \\
\hline \multicolumn{4}{|l|}{ Market-Adjusted Estimates } \\
\hline $\begin{array}{l}\text { Mean (median) Market-Adjusted Final Offer } \\
\text { Price/Sales } \\
\text { Mean (median) Market-Adjusted Final Offer } \\
\text { Price/Book }\end{array}$ & $\begin{array}{c}0.364 \\
(0.203) \\
0.976 \\
(0.338)\end{array}$ & $\begin{array}{c}1.465 \\
(0.633) \\
1.927 \\
(1.292)\end{array}$ & $\begin{array}{c}1.88^{*} \\
(2.80)^{* * *} \\
0.90 \\
(2.02 * *)\end{array}$ \\
\hline
\end{tabular}


Table 7

Pre-Law Propensity to Delist or Dilute

Marginal effects, based on logit regressions of propensities to delist or dilute minority shareholders. Dependent variable in delisting (dilution) models equals 1 if a firm is delisted from the BSE (issues more than $20 \%$ new equity) during 1999-2001, 0 otherwise. Private Control dummy equals 1 if a non-state shareholder owns a majority stake; 0 otherwise. Ownership is measured prior to delisting (dilution), or at year-end 2001 if no delisting (dilution) occurs. Stake 1-Stake 2 equals difference between fractional stakes of the largest and second largest blockholder. Shapley values are calculated using three blockholders (largest and second largest blockholder, third blockholder is the combined stake of all financial institutions) and an ocean of other shareholders. Shapley wedge $=$ Shapley value/ equity stake of largest blockholder. Sales growth is fractional sales growth from 1998 to 1999. Export/Sales is fraction of sales outside of Bulgaria in 1996 (more recent data is not available). Leverage $=($ Long-Term + ShortTerm Debt)/Total Assets. All regressions include industry dummies. $t$-statistics are in parenthesis. $*, * *, * * *$ denote significance at $10 \%, 5 \%$, and $1 \%$ level, respectively. Significant results, at $5 \%$ level or better, are in boldface.

\begin{tabular}{|c|c|c|c|c|}
\hline \multirow{2}{*}{$\begin{array}{l}\text { Logit regression of propensity to: } \\
\text { Model: }\end{array}$} & \multicolumn{2}{|c|}{ Delist } & \multicolumn{2}{|c|}{ Dilute } \\
\hline & (1) & (2) & (1) & (2) \\
\hline \multirow[t]{2}{*}{ State minority stake dummy } & $0.192 * * *$ & & -0.038 & \\
\hline & $(4.01)$ & & $(-1.34)$ & \\
\hline \multirow[t]{2}{*}{ Private control dummy } & $0.162 * * *$ & & -0.025 & \\
\hline & (2.68) & & $(-0.72)$ & \\
\hline \multirow[t]{2}{*}{ Stake of largest private shareholder } & -0.030 & & 0.138 & \\
\hline & $(-0.10)$ & & $(0.70)$ & \\
\hline \multirow[t]{2}{*}{ Stake 1 - Stake 2} & $-0.573 * * *$ & & 0.220 & \\
\hline & $(-2.59)$ & & $(1.63)$ & \\
\hline \multirow[t]{2}{*}{ Shapley value of largest private shareholder } & & -0.158 & & $0.277 * * *$ \\
\hline & & $(-1.49)$ & & (4.36) \\
\hline \multirow[t]{2}{*}{ Shapley value of State } & & -0.185 & & $0.218 * * *$ \\
\hline & & $(-1.23)$ & & $(2.65)$ \\
\hline \multirow[t]{2}{*}{ Shapley wedge } & & 0.062 & & $-0.218 * * *$ \\
\hline & & $(0.64)$ & & $(-3.72)$ \\
\hline \multirow[t]{2}{*}{ Ln(sales) in 1999} & $-0.113 * * *$ & $-0.122 * * *$ & 0.007 & 0.012 \\
\hline & $(-6.32)$ & $(-7.12)$ & $(0.82)$ & $(1.34)$ \\
\hline \multirow[t]{2}{*}{ Exports/sales in 1996} & -0.038 & -0.102 & -0.053 & -0.028 \\
\hline & $(-0.46)$ & $(-1.28)$ & $(-1.08)$ & $(-0.58)$ \\
\hline \multirow[t]{2}{*}{ Positive net income in 1999 dummy } & $0.147 * * *$ & $0.125 * * *$ & -0.033 & -0.028 \\
\hline & $(2.90)$ & (2.58) & $(-1.15)$ & $(-0.98)$ \\
\hline \multirow[t]{2}{*}{ Operating margin in 1999} & $0.335 * * *$ & $0.337 * * *$ & 0.082 & 0.074 \\
\hline & (3.36) & (3.53) & $(1.17)$ & $(1.04)$ \\
\hline \multirow[t]{2}{*}{ Sales growth from 1998 to 1999} & 0.020 & 0.014 & -0.013 & -0.013 \\
\hline & $(0.51)$ & $(0.39)$ & $(-0.58)$ & $(-0.58)$ \\
\hline \multirow{2}{*}{ Leverage in 1999} & -0.113 & -0.079 & $0.226 * * *$ & $0.228 * * *$ \\
\hline & $(-0.62)$ & $(-0.45)$ & $(2.58)$ & $(2.60)$ \\
\hline Pseudo $\mathrm{R}^{2}$ & 0.19 & 0.14 & 0.13 & 0.10 \\
\hline Firms undergoing delisting (dilution) & 399 & 399 & 95 & 95 \\
\hline Firms in sample at start of period & 647 & 647 & 647 & 647 \\
\hline
\end{tabular}


Table 8

\section{Substitution between Equity Tunneling and Cash-Flow Tunneling}

Firm fixed effects regressions of yearly ROA, defined as EBIT(t)/Total Assets(t-1) and winsorized at 1\%/99\%. We drop firms with no observation of the dependent variable either before or after the law change. Postlaw dummy $=1$ for 2002 and 2003,0 for 2000 and 2001. Delisting and dilution propensities are estimated using models (1) and (2) from Table 7. For each model we run two specifications -without and with controls for leverage and ownership. Leverage, Shapley values, and Shapley wedge are defined in Table 7. $t$-statistics, using White's robust standard errors, are in parentheses. All regressions include year dummies. $*, * *, * * *$ denote significance at $10 \%, 5 \%$, and $1 \%$ level, respectively. Significant results, at $5 \%$ level or better, are in boldface. Marginally significant results $(\mathrm{p}<.10)$ are indicated with italics.

\begin{tabular}{|c|c|c|c|c|}
\hline \multirow{3}{*}{$\begin{array}{l}\text { Dependent Variable: } \\
\text { Propensities based on: }\end{array}$} & \multicolumn{4}{|c|}{ ROA } \\
\hline & \multicolumn{2}{|c|}{ Model (1) } & \multicolumn{2}{|c|}{ Model (2) } \\
\hline & (1) & (2) & (3) & (4) \\
\hline Postlaw * delisting propensity & $\begin{array}{c}-0.173^{*} \\
(-1.96)\end{array}$ & $\begin{array}{c}-0.200 * * \\
(-2.08)\end{array}$ & $\begin{array}{c}-0.213^{* *} \\
(-2.10)\end{array}$ & $\begin{array}{c}-0.242 * * \\
(-2.21)\end{array}$ \\
\hline Postlaw * dilution propensity & $\begin{array}{c}-0.313^{* *} \\
(-2.15)\end{array}$ & $\begin{array}{c}-0.346^{* *} \\
(-2.27)\end{array}$ & $\begin{array}{c}-0.445 * * * \\
(-2.48)\end{array}$ & $\begin{array}{c}-0.478 * * * \\
(-2.61)\end{array}$ \\
\hline Leverage & & $\begin{array}{c}-0.148 * * \\
(-2.17)\end{array}$ & & $\begin{array}{c}-0.148 * * \\
(-2.20)\end{array}$ \\
\hline Shapley Private & & $\begin{array}{l}-0.036 \\
(-0.64)\end{array}$ & & $\begin{array}{c}-0.054 \\
(-0.97)\end{array}$ \\
\hline Shapley State & & $\begin{array}{l}0.050 \\
(0.34)\end{array}$ & & $\begin{array}{l}0.048 \\
(0.32)\end{array}$ \\
\hline Shapley Wedge & & $\begin{array}{l}0.044 \\
(0.89)\end{array}$ & & $\begin{array}{l}0.064 \\
(1.26)\end{array}$ \\
\hline Postlaw dummy & $\begin{array}{l}0.189 * * * \\
(2.78)\end{array}$ & $\begin{array}{c}0.215 * * * \\
(2.90)\end{array}$ & $\begin{array}{c}0.227 * * * \\
(2.96)\end{array}$ & $\begin{array}{c}0.255^{* * *} \\
(3.08)\end{array}$ \\
\hline $\begin{array}{l}\text { Mean (median) pre-law ratio } \\
\text { Number of firms (observations) }\end{array}$ & & & & \\
\hline
\end{tabular}


Table 9

\section{Tunneling Propensities and Changes in Firm Valuation}

Firm fixed-effects regressions of quarterly Tobin's $q$, estimated as (book value of assets + market value of equity - book value of equity)/(book value of assets). Postlaw dummy = 1 during 2002 and 2003, 0 during 2000 and 2001. We drop observations for fourth quarter of 2001, and drop firms with no observed $q$ either before or after the law change. Delisting and dilution propensities are estimated using models (1) and (2) from Table 7. For each model we run two specifications -without and with controls for ROA, leverage and ownership. ROA is defined in Table 8; leverage, Shapley values, and Shapley wedge are defined in Table 7. All regressions include quarter dummies. $t$-statistics, using White's robust standard errors, are in parentheses. *, **, *** denote significance at $10 \%, 5 \%$, and $1 \%$ level, respectively. Significant results, at 5\% level or better, are in boldface. Marginally significant results $(\mathrm{p}<.10)$ are indicated with italics.

\begin{tabular}{|c|c|c|c|c|}
\hline \multirow{3}{*}{$\begin{array}{l}\text { Dependent variable: } \\
\text { Propensities based on: }\end{array}$} & \multicolumn{4}{|c|}{ Tobin's q } \\
\hline & \multicolumn{2}{|c|}{ Model (1) } & \multicolumn{2}{|c|}{ Model (2) } \\
\hline & (1) & (2) & (3) & (4) \\
\hline Postlaw * delisting propensity & $\begin{array}{l}0.355^{* * *} \\
(2.65)\end{array}$ & $\begin{array}{l}0.372^{* * *} \\
(2.77)\end{array}$ & $\begin{array}{l}0.243^{*} \\
(1.84)\end{array}$ & $\begin{array}{c}0.271 * * \\
(2.03)\end{array}$ \\
\hline Postlaw * dilution propensity & $\begin{array}{c}0.643^{* * *} \\
(3.05)\end{array}$ & $\begin{array}{c}0.702^{* * *} \\
(3.35)\end{array}$ & $\begin{array}{c}0.610 * * * \\
(2.48)\end{array}$ & $\begin{array}{c}0.691 * * * \\
(2.88)\end{array}$ \\
\hline ROA & & $\begin{array}{l}0.012 \\
(0.09)\end{array}$ & & $\begin{array}{l}0.006 \\
(0.04)\end{array}$ \\
\hline Leverage & & $\begin{array}{l}-0.031 \\
(-0.20)\end{array}$ & & $\begin{array}{l}-0.084 \\
(-0.53)\end{array}$ \\
\hline Shapley Private & & $\begin{array}{c}0.174 * * * \\
(2.69)\end{array}$ & & $\begin{array}{c}0.184 * * * \\
(2.70)\end{array}$ \\
\hline Shapley State & & $\begin{array}{c}0.237 * * \\
(2.17)\end{array}$ & & $\begin{array}{c}0.203^{*} \\
(1.84)\end{array}$ \\
\hline Shapley Wedge & & $\begin{array}{l}0.055 \\
(1.18)\end{array}$ & & $\begin{array}{l}0.033 \\
(0.68)\end{array}$ \\
\hline Postlaw dummy & $\begin{array}{c}-0.234 * * * \\
(-2.36) \\
\end{array}$ & $\begin{array}{c}-0.256 * * * \\
(-2.62) \\
\end{array}$ & $\begin{array}{l}-0.178^{*} \\
(-1.79) \\
\end{array}$ & $\begin{array}{c}-0.204 * * \\
(-2.12) \\
\end{array}$ \\
\hline $\begin{array}{l}\text { Mean (median) pre-law ratio } \\
\text { Number of firms (observations) }\end{array}$ & & $\begin{array}{l}0 \\
12\end{array}$ & & \\
\hline
\end{tabular}


Table 10

\section{Difference-in-Differences Regressions: After-minus-Before Changes in Firm Valuation}

Difference-in-differences regressions of quarterly Tobin's $q$, estimated as (book value of assets + market value of equity - book value of equity)/(book value of assets). Postlaw dummy = 1 during 2002 and 2003, 0 during 2000 and 2001 . We drop observations for fourth quarter of 2001, and drop firms with no observed $q$ either before or after the law change. The ownershipbased control group is firms with no $20 \%$ blockholder. Private $50 \%+$ dummy (Private $20-50 \%$ dummy) $=1$ for firms with a private majority owner (a 20 to 50\% private blockholder). The propensity-based control group is firms that have either above median propensity to dilute or above median propensity to delist. All other firms are included in the "high tunneling propensity" treatment group. Propensities are calculated using model 1 in Table 7. For each model we run two specifications -without and with controls for ROA, leverage and ownership. ROA is measured as in Table 8; leverage, Shapley values, and Shapley wedge are defined in Table 7. All regressions include firm fixed effects and quarter dummies. T-statistics, using White's robust standard errors, are in parentheses. $*, * *, * * *$ denote significance at $10 \%, 5 \%$, and $1 \%$ level, respectively. Significant results, at $5 \%$ level or better, are in boldface. Marginally significant results $(\mathrm{p}<.10)$ are indicated with italics.

\begin{tabular}{|c|c|c|c|c|}
\hline \multirow{3}{*}{$\begin{array}{l}\text { Dependent variable: } \\
\text { Control group based on: }\end{array}$} & \multicolumn{4}{|c|}{ Tobin's q } \\
\hline & \multicolumn{2}{|c|}{ Ownership } & \multicolumn{2}{|c|}{ Tunneling Propensities } \\
\hline & (1) & $(2)$ & (3) & (4) \\
\hline Postlaw * Private $50 \%+$ & $\begin{array}{l}0.766 * * * \\
(3.28)\end{array}$ & $\begin{array}{c}0.779 * * * \\
(3.34)\end{array}$ & & \\
\hline Postlaw * Private $20-50 \%$ & $\begin{array}{c}0.769 * * * \\
(3.29)\end{array}$ & $\begin{array}{c}0.764 * * * \\
(3.29)\end{array}$ & & \\
\hline Postlaw * High Tunneling Propensity & & & $\begin{array}{c}0.250 * * * \\
(3.55)\end{array}$ & $\begin{array}{c}0.264 * * * \\
(3.80)\end{array}$ \\
\hline ROA & & $\begin{array}{l}-0.039 \\
(-0.40)\end{array}$ & & $\begin{array}{l}0.007 \\
(0.05)\end{array}$ \\
\hline Leverage & & $\begin{array}{l}-0.152 \\
(-1.02)\end{array}$ & & $\begin{array}{l}-0.123 \\
(-0.78)\end{array}$ \\
\hline Shapley Private & & $\begin{array}{c}0.169 * * * \\
(2.82)\end{array}$ & & $\begin{array}{c}0.147 * * \\
(2.31)\end{array}$ \\
\hline Shapley State & & $\begin{array}{l}0.105 \\
(1.21)\end{array}$ & & $\begin{array}{c}0.210 * * \\
(2.08)\end{array}$ \\
\hline Shapley Wedge & & $\begin{array}{l}-0.010 \\
(-0.19)\end{array}$ & & $\begin{array}{l}0.064 \\
(1.36)\end{array}$ \\
\hline Postlaw dummy & $\begin{array}{c}-0.711 * * * \\
(-3.03)\end{array}$ & $\begin{array}{c}-0.713 * * * \\
(-3.07) \\
\end{array}$ & $\begin{array}{r}-0.168 * \\
(-2.19) \\
\end{array}$ & $\begin{array}{c}-0.177^{* *} \\
(-2.39) \\
\end{array}$ \\
\hline $\begin{array}{l}\text { Number of firms } \\
\text { Number of observations }\end{array}$ & & & & \\
\hline
\end{tabular}




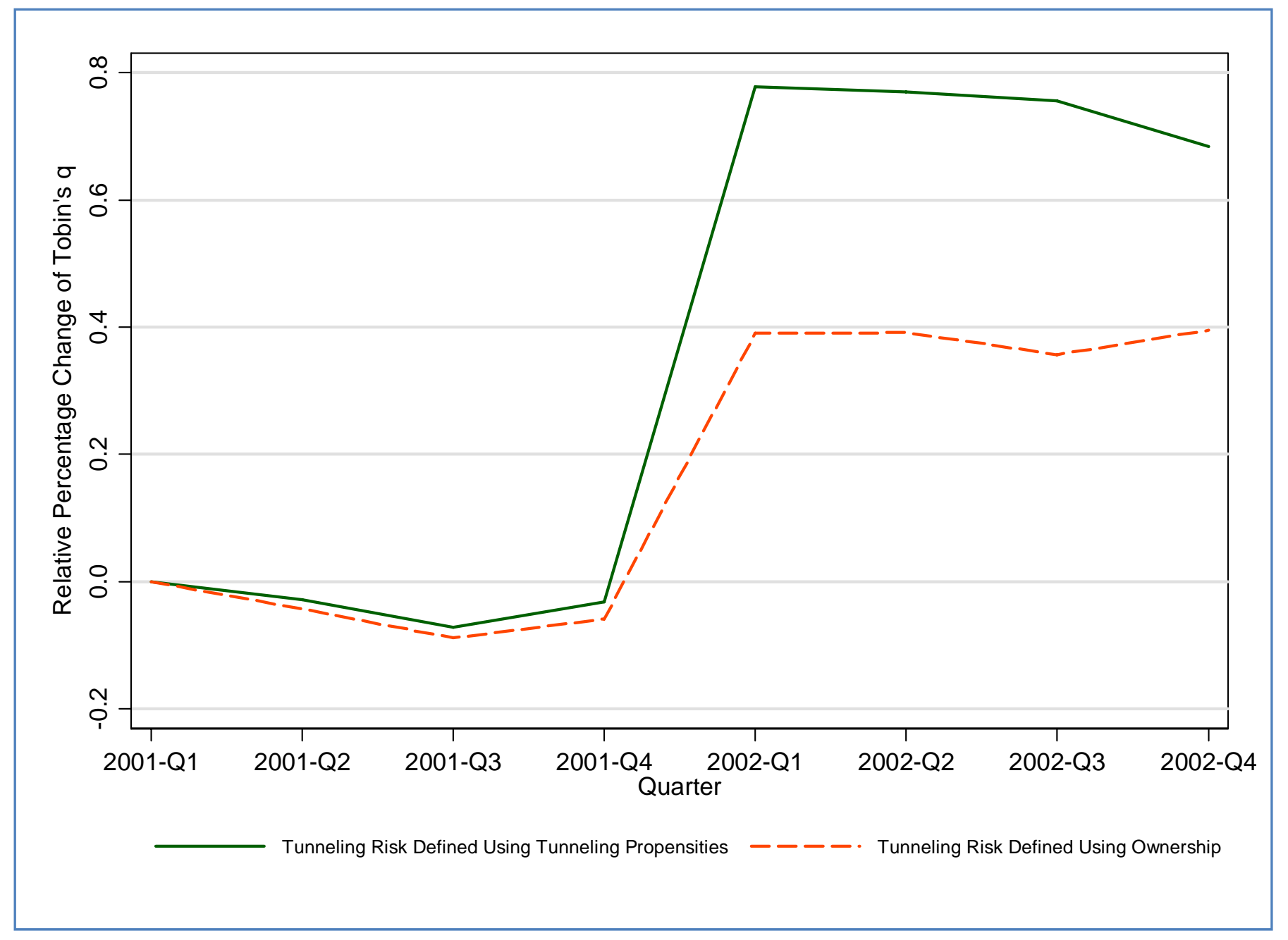

Figure 1. Percentage Change in Tobin's $q$ for High-Equity-Tunneling-Risk Firms Relative to Low-EquityTunneling-Risk Firms

Quarterly time series of the percentage change in mean Tobin's $q$, with the first quarter of 2001 as the base quarter, for firms at high equity tunneling risk minus the percentage change in mean $q$ for low-tunneling-risk firms, using a balanced panel of firms with non-missing valuation multiples for all eight quarters of 2001-2002. For solid line, low-equity-tunneling-risk firms are firms that have below-median propensity for both delisting and dilution, estimated using logit model (1) of Table 7 . Other firms are high-equity-tunneling-risk. For dashed line, low-equity-tunneling-risk firms are firms with no majority owner. Other firms are high equity tunneling risk. 